\title{
Prescribed burning of logging slash in the boreal forest of Finland: emissions and effects on meteorological quantities and soil properties
}

A. Virkkula ${ }^{1,2}$, J. Levula ${ }^{1,3}$, T. Pohja ${ }^{3}$, P.P. Aalto ${ }^{1}$, P. Keronen ${ }^{1}$, S. Schobesberger ${ }^{1}$, C. B. Clements ${ }^{4}$, L. Pirjola ${ }^{5}$, A.-J. Kieloaho ${ }^{1}$, L. Kulmala ${ }^{6}$, H. Aaltonen ${ }^{2,7}$, J. Patokoski ${ }^{1}$, J. Pumpanen ${ }^{7}$, J. Rinne ${ }^{1}$, T. Ruuskanen ${ }^{1}$, M. Pihlatie ${ }^{1}$, H. E. Manninen ${ }^{1}$, V. Aaltonen ${ }^{2}$, H. Junninen ${ }^{1}$, T. Petäjä ${ }^{1}$, J. Backman ${ }^{1}$, M. Dal Maso ${ }^{1}$, T. Nieminen ${ }^{1}$, T. Olsson ${ }^{2}$, T. Grönholm ${ }^{8}$, J. Aalto ${ }^{3}$, T. H. Virtanen ${ }^{2}$, M. Kajos ${ }^{1}$, V.-M. Kerminen ${ }^{1}$, D. M. Schultz ${ }^{1,2,9}$, J. Kukkonen ${ }^{2}$, M. Sofiev ${ }^{2}$, G. De Leeuw ${ }^{1,2}$, J. Bäck ${ }^{7}$, P. Hari ${ }^{7}$, and M. Kulmala ${ }^{1}$

${ }^{1}$ Department of Physics, University of Helsinki, 00014, Helsinki, Finland

${ }^{2}$ Finnish Meteorological Institute, Erik Palménin aukio 1, 00101, Helsinki, Finland

${ }^{3}$ Hyytiälä Forestry Field Station, University of Helsinki, 35500, Korkeakoski, Finland

${ }^{4}$ Department of Meteorology and Climate Science, San José State University, San José, CA 95192, USA

${ }^{5}$ Department of Technology, Metropolia University of Applied Sciences, 00079, Helsinki, Finland

${ }^{6}$ Finnish Forest Research Institute, P.O. Box 18, Vantaa, Finland

${ }^{7}$ Department of Forest Sciences, P.O. Box 27, University of Helsinki, 00014, Helsinki, Finland

${ }^{8}$ Finnish Environment Institute, Joensuu Office, 80101 Joensuu, Finland

${ }^{9}$ Centre for Atmospheric Science, School of Earth, Atmospheric and Environmental Sciences, University of Manchester, Simon Building, Oxford Road, Manchester, M13 9PL, UK

Correspondence to: A. Virkkula (aki.virkkula@helsinki.fi)

Received: 20 June 2013 - Published in Atmos. Chem. Phys. Discuss.: 22 August 2013

Revised: 20 January 2014 - Accepted: 3 March 2014 - Published: 7 May 2014

\begin{abstract}
A prescribed fire experiment was conducted on 26 June 2009 in Hyytiälä, Finland, to study aerosol and trace gas emissions from prescribed fires of slash fuels and the effects of fire on soil properties in a controlled environment. A 0.8 ha forest near the SMEAR II measurement station (Station for Measuring Ecosystem-Atmosphere Relations) was cut clear; some tree trunks, all tree tops and branches were left on the ground and burned. The amount of burned organic material was $\sim 46.8$ tons (i.e., $\sim 60$ tons ha ${ }^{-1}$ ). The flaming phase lasted $2 \mathrm{~h} 15 \mathrm{~min}$, the smoldering phase $3 \mathrm{~h}$. Measurements were conducted on the ground with both fixed and mobile instrumentation, and in the air from a research aircraft. In the middle of the burning area, $\mathrm{CO}_{2}$ concentration peaked around 2000-3000 ppm above the baseline, and peak vertical flow velocities were $\sim 9 \mathrm{~m} \mathrm{~s}^{-1}$, as measured with a $10 \mathrm{~Hz}$ 3-D sonic anemometer placed within the burn area. In the mobile measurements the peak particle number concentrations were approximately $1-2 \times 10^{6} \mathrm{~cm}^{-3}$ in the plume at a
\end{abstract}

distance of 100-200 $\mathrm{m}$ from the burn area. On the ground at the SMEAR II station the geometric mean diameter of the mode with the highest concentration was $80 \pm 1 \mathrm{~nm}$ during the flaming phase and in the middle of the smoldering phase, but, at the end of the smoldering phase, the largest mode was $122 \mathrm{~nm}$. In the volume size distributions, geometric mean diameter of the largest volume mode was $153 \mathrm{~nm}$ during the flaming phase and $300 \mathrm{~nm}$ during the smoldering phase. The lowest single-scattering albedo of the groundlevel measurements was 0.7 in the flaming-phase plume and $\sim 0.9$ in the smoldering phase. Elevated concentrations of several volatile organic compounds (VOC) (including acetonitrile, a biomass burning marker) were observed in the smoke plume at ground level. Measurements at the forest floor (i.e., a richly organic layer of soil and debris, characteristic of forested land) showed that VOC fluxes were generally low and consisted mainly of monoterpenes, and VOC flux peaked after the burning. After one year, the fluxes had 
nearly stabilized close to the level before the burning. The clear-cutting and burning of slash increased the total longterm $\mathrm{CO}_{2}$ release from the soil, and altered the physical, chemical and biological properties of the soil, such as increased the available nitrogen contents of the soil, which in turn, affected the long-term fluxes of greenhouse gases.

\section{Introduction}

Gaseous and aerosol emissions from wildfires have significant climatic (e.g., Bowman et al., 2009; Grell et al., 2011) and health effects (Naeher et al., 2007; Johnston et al., 2012) on local to hemispheric scales. In the Northern Hemisphere, smoke from wildfires can be transported over long distances from the boreal forest areas in Eurasia and North America to the Arctic (e.g., Radke et al., 1991; Goldammer et al., 1996; Lavoué et al., 2000; Randerson et al., 2006; Stohl, 2006; Law and Stohl, 2007; Shindell et al., 2008; Paris et al., 2009; Hirdman et al., 2010; Lamarque et al., 2010; AMAP, 2011, 2011). Smoke originating from wildfires and agricultural fires in eastern Europe can affect extensive regions in western and central Europe and the Arctic (Law and Stohl, 2007; Saarnio et al., 2010; Klein et al., 2012). Fires directly emit long-lived greenhouse gases (e.g., carbon dioxide $\left(\mathrm{CO}_{2}\right)$, nitrous oxide $\left(\mathrm{N}_{2} \mathrm{O}\right)$ ) and short-lived greenhouse gases (e.g., methane $\left(\mathrm{CH}_{4}\right)$ ), countless volatile organic compounds (VOC) and nitrogen oxides $\left(\mathrm{NO}_{\mathrm{x}}\right)$ that are precursors of ozone $\left(\mathrm{O}_{3}\right)$, a short-lived greenhouse gas (e.g., Andreae and Merlet, 2001; Akagi et al., 2011; Simpson et al., 2011; Jaffe and Widger, 2012; Yokelson et al., 2013). The particles emitted by fires are short-lived climate forcers that can have either negative or positive forcing effects, depending on their optical and cloud-forming properties and on the albedo of the underlying surface (e.g., Randerson et al., 2006; Quinn et al., 2008; Ramanathan and Carmichael, 2008). Black carbon emitted from wildfires may get transported and deposited on snow or ice, where it has a positive radiative forcing due to the reduction of the albedo of the surface (e.g., Ramanathan and Carmichael, 2008; Bond et al., 2013). Wildfires also change the surface albedo of the forests, which can impact the climate. For instance, Randerson et al. (2006) showed that the warming impact of increasing boreal forest fires may be limited or even result in regional cooling because of the loss of canopy overstory and consequently higher albedo values during winter and spring.

Active wildfires and burned areas can be observed from space by using satellite imagery (e.g., Flannigan and Haar, 1986; Lentile et al., 2006; French et al., 2008; Sofiev et al., 2009; Giglio et al., 2010). Satellite images give information on the area that is burning, but not on the amount of fuel consumed or smoke emitted. van der Werf et al. (2010) used a biogeochemical model and satellite-derived estimates of area burned, fire activity, and plant productivity to calculate the total global carbon emissions due to deforestation, savanna, forest, agricultural and peat fires. They estimated that the boreal region accounted for about $9 \%$ of total global carbon emissions from fires. To estimate the amount of aerosols and trace gases emitted, emission factors, defined as the amount of emitted aerosol or trace gases per mass unit of burned biomass, are needed. Recent reviews of emission factors include Andreae and Merlet (2001), Reid et al. (2005a, b), Janhäll et al. (2010), Akagi et al. (2011), Simpson et al. (2011) and Yokelson et al. (2013).

Detailed measurements of gas and aerosol emissions are difficult to obtain in real wildfires. The fire may be too large and uncontrolled, and placing instrumentation near the fire may be difficult. To address these problems, researchers often choose the more controlled environment of a prescribed burn to study fires. Prescribed fire is used for fire prevention, site preparation and maintaining habitat quality (Bowman et al., 2009, 2011). The total area of prescribed fire in the USA was nearly 1 million hectares during 2011 (National Interagency Fire Center, 2011). The areas of prescribed burns that have been used for research vary by several orders of magnitude. Radke et al. (1991) described measurements of smokes from 17 biomass fuel fires, including 14 prescribed fires and 3 wildfires primarily in the temperate zone of North America. The prescribed fires were in forested lands and logging debris and the areas burned varied from 10 to 700 hectares (ha). The "Smoke, Clouds and Radiation - California", SCARC, experiment was conducted in September 1994 in the Pacific Northwest of the United States (Kaufman et al., 1996; Hobbs et al., 1996; Gassó and Hegg, 1998). In SCAR-C the emissions from clear-cut prescribed burns with areas ranging from 19.4 ha to 44.5 ha were measured with instruments on an aeroplane (Hobbs et al., 1996). Close to natural wildfires were for instance the Bor Forest Island Fire Experiment in which the forest on a 50 ha Siberian island was burned in 1993 (FIRESCAN Science Team, 1996), the International Crown Fire Modelling Experiment (ICFME) that involved 18 experimental high-intensity crown fires ranging from 0.56 ha to 2.25 ha in size in Canada's Northwest Territories between 1995 and 2001 (Cofer III et al., 1998; Conny and Slater, 2002; Alexander et al., 2004; Payne et al., 2004; Stocks et al., 2004), the FROSTFIRE experiment in which approximately 365 ha of black spruce was burned in Alaska in 1999 (Ferguson et al., 2003; Hinzman et al., 2003; Cahill et al., 2008), and the Fire Effects in the Boreal Eurasian Forests (FIRE BEAR) experiments where 22 plots of approximately 4 ha were burned in central Siberia in 2000 and 2001 (McRae et al., 2006).

In Finland, there is a long tradition of managed forest burning. The use of burn-beating cultivation to produce corn and root crops existed for several hundred years and ended around 1910 (Heikinheimo, 1915). In the 1920s, prescribed burning of clear-cut areas began (Viro, 1969). The idea of prescribed burning is to burn the logging waste, surface vegetation and the uppermost part of the raw humus layer. This 
practise promotes the regeneration of the tree stand and is normally followed by the seeding of Scots pine and occasionally silver birch. Prescribed burning was widely used in Finland in the 1950s and 1960s, with over 10000 ha typically burned annually. Since then, more effective mechanical soilpreparation methods superseded prescribed burning (Finnish Forest Research Institute, 1991). One reason for the reduction in the areas burned was also the fear of the fire getting out of control. Nowadays $500-1000$ ha is burned each year (Finnish Forest Research Institute, 2011). The main reason of the present-day burnings is to enhance biodiversity.

The use and effects of managed burning of forest are investigated at the University of Helsinki. As part of this work, we conducted a prescribed burning about $300-500 \mathrm{~m}$ south-southwest from the SMEAR II measurement station (Station for Measuring Ecosystem-Atmosphere Relations; Hari and Kulmala, 2005) in Hyytiälä, Finland $\left(61^{\circ} 50^{\prime} 47^{\prime \prime} \mathrm{N}\right.$, $24^{\circ} 17^{\prime} 42^{\prime \prime} \mathrm{E}, 181 \mathrm{~m}$ a.m.s.l.) on 26 June 2009. The experiment was an integral part of two large projects: the European Integrated project on Aerosol Cloud Climate and Air Quality Interactions (EUCAARI; Kulmala et al., 2011) and the Integrated Monitoring and Modelling System for Wildland Fires (IS4FIRES; Saarikoski et al., 2007; Sofiev et al., 2009).

A 0.8 ha forest area near SMEAR II was cut clear. Some tree trunks, all tree tops and all branches were left on the ground and burned. The prescribed burning therefore represents fires in a forested area containing clear-cut blocks of logging slash. It does not represent fires in a full-grown boreal forest. The burned area is small compared with the experiments mentioned above (e.g., Radke et al., 1991; Hobbs et al., 1996; Hinzman et al., 2003; McRae et al., 2006).

During burning, we conducted measurements on the ground and in the air. Ground-based instrumentation included the SMEAR II station and meteorological and ecological measurements on and around the site. We measured ground-level dispersion of particles and trace gases both by using the research van Sniffer and by walking in the forest with portable particle counters at different distances from the burning area. We measured the vertical and horizontal dispersion of the plume with instruments installed in a Cessna 172. Soil temperature, humidity and trace gas efflux were measured within the burn and unburned reference areas.

The general goal of the experiment was to collect data for estimating the effect of fires on air quality and climate. The specific goals and objectives were (1) to obtain emission factors of aerosols and gases, (2) to characterize the climatically relevant physical properties of the smoke aerosol (e.g., size, optical properties), (3) to quantify the connections between ground-based smoke observations and satellite remote sensing, (4) to obtain data for testing an improving model of atmospheric dispersion of the fire plume, and (5) to quantify the changes taking place in soil carbon stocks and greenhouse gas $\left(\mathrm{CO}_{2}, \mathrm{CH}_{4}\right.$ and $\left.\mathrm{N}_{2} \mathrm{O}\right)$ fluxes following clear-cutting and prescribed burning. The experiment fulfils the requirements to be called a prescribed fire: it is the appli- cation of prescribed burning in a skilled manner, under exacting weather conditions, in a definite place, and to achieve specific results (Wade and Lunsford, 1989; Alexander and Thomas, 2006).

The purpose of this article is to provide an overview of the experiment by describing the preparations for the experiment, estimates of burned biomass, meteorological conditions during the experiment, characterization of the aerosols and gases emitted, and the observed dispersion of aerosols both at ground level and in the airborne measurements. The aim is also to evaluate the performance of the setup for repeating similar experiments. Following the recommendation of Alexander (2010) for the documentation of prescribed fires, we also present photographs from the different phases of the fire.

\section{Methods}

\subsection{The site preparation}

A suitable burn area was found in summer 2008 approximately $300-500 \mathrm{~m}$ south-southwest of the measurement buildings of the SMEAR II station. We selected the site to be burned so that prevailing southwesterly wind, specifically, with a wind direction from $180-200^{\circ}$, would bring the smoke aerosols and gases to the SMEAR II station during the burning. To determine the suitability of the burn area, the $30 \mathrm{~min}$ averaged wind direction from the SMEAR II mast data over the layer $33.6 \mathrm{~m}$ to $73 \mathrm{~m}$ was averaged from every month of June of the years 1996-2008 to get the mean wind direction above the treetops. Based on this climatology, wind directions of $180-200^{\circ}$ occurred $9.6 \%$ of the time with no particular preference for a specific time of day. When the wind occurred in this direction, the average wind speed was $3.1 \pm 1.3 \mathrm{~m} \mathrm{~s}^{-1}$ and $86 \%$ of wind speeds were less than the $5 \mathrm{~m} \mathrm{~s}^{-1}$ threshold required for a safe burn.

In addition to the burn area, we also selected a control site near the burning area (Fig. 1). At the burn site, there was a mature spruce-dominated (Picea abies (L.) H. Karst. known as a Norway Spruce or European Spruce) stand with a stem volume per hectare of about $400 \mathrm{~m}^{3}$. The area was cut clear in February 2009. After the clear-cutting most tree trunks were transported away; some of them and all tree tops and all branches were left on the ground in the burn area. An estimation of the biomass was done before and after the burning.

\subsection{Estimation of burned organic material}

The tree stand was measured in July 2008 from 13 relascope plots from which the species, diameter at breast height $(\mathrm{DBH})$, diameter at the height of $6.0 \mathrm{~m}$, the living crown length and height $(\mathrm{H})$ were recorded for each tree. Then, biomass models (Repola et al., 2007) were used to calculate the biomass for the different tree components. The merchantable wood was harvested in February 2009, after 
a)

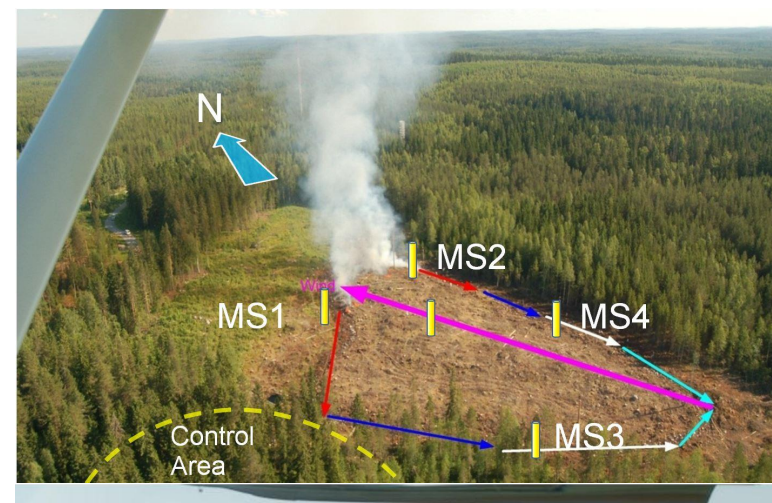

b)

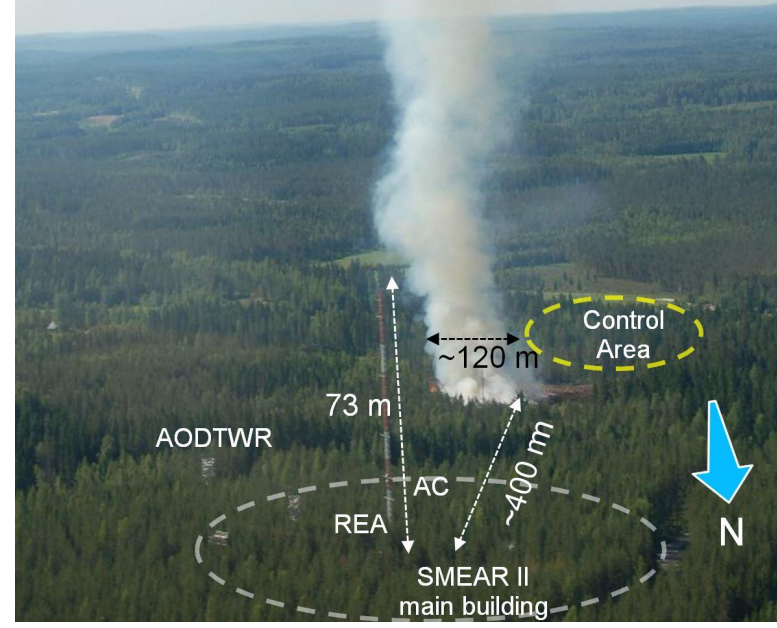

Fig. 1. Aerial photographs of the study site during the flaming phase. (a) From the south, with the progress of the ignition described by the red, blue, white and light blue arrows, and the average wind direction by the pink arrow. The yellow bars denote the poles (not in scale) with meteorological sensors (MS1-MS4) on top. (b) From the north at approximately $300 \mathrm{~m}$ above ground level. The majority of the aerosol and gas measurement instrumentation of SMEAR II is located within the dashed white oval. The control area is within the yellow oval. The blue arrow points approximately north. AC: aerosol cottage; REA: relaxed eddy accumulation cottage; AODTWR: Aerosol Optical Depth Tower.

which all the non-merchantable trees were also felled. After burning, the amount of unburned wood was sampled from 21 plots of $0.5 \mathrm{~m}^{2}$. All the wood was collected from the plots, dried $\left(24 \mathrm{~h}, 105^{\circ} \mathrm{C}\right)$ and weighed. The amount of burned tree biomass was finally calculated as an extraction of the non-merchantable tree biomass (treetops, branches and non-merchantable trees) and unburned wood biomass. The surface vegetation, dominated by feather mosses and dwarf shrubs, was systematically sampled from 13 plots of $0.0625 \mathrm{~m}^{2}$ in July-August. The vegetation was cut along the surface of the litter layer, collected, dried $\left(24 \mathrm{~h}, 105^{\circ} \mathrm{C}\right)$ and weighed. The organic matter content of the uppermost, organic soil layers (litter layer and humus layer) was systemat- ically sampled both before the clear-cutting in August 2008 and soon after the burning in July 2009. A total of 25 samples was collected on both occasions with a $45 \mathrm{~mm}$-diameter soil auger. The samples were dried $\left(24 \mathrm{~h}, 105^{\circ} \mathrm{C}\right)$ and weighed. The mass of burned organic material in the organic soil layer was calculated as the difference of the mass before and after the burning.

\subsection{Gas, aerosol and meteorological measurements}

A list of the measurements conducted during the campaign is presented in Table 2. In short, trace-gas concentrations, aerosol physical properties aerosol chemical composition, and meteorological parameters were measured both at fixed sites and on mobile platforms.

\subsubsection{Measurements at fixed positions}

At the SMEAR II measurement station, both aerosols and gases were measured with the setup described by Hari and Kulmala (2005). Measurements were conducted at five different locations: the main building of the station, the $73 \mathrm{~m}$ high SMEAR II mast, the aerosol cottage, the relaxed eddy accumulation (REA) cottage, and the aerosol optical depth tower (AODTWR) about $100 \mathrm{~m}$ east of the aerosol cottage. The above measurements are within $300-400 \mathrm{~m}$ of the burn area (Fig. 1b).

The concentrations of $\mathrm{CO}_{2}, \mathrm{H}_{2} \mathrm{O}, \mathrm{O}_{3}, \mathrm{NO}, \mathrm{NO}_{\mathrm{x}}, \mathrm{SO}_{2}$ and $\mathrm{CO}$ were measured alternately at six heights along the $73 \mathrm{~m}$ mast. The instruments were located in the main building, and sample air was taken through six sample lines consisting of polytetrafluoroethylene (PTFE) tubes, each $100 \mathrm{~m}$ long with $14 \mathrm{~mm}$ inner diameter and $16 \mathrm{~mm}$ outer diameter. There was a continuous flow rate of $45 \mathrm{~L} \mathrm{~min}^{-1}$ in the lines, which resulted in an estimated lag time of $20 \mathrm{~s}$. For each gas component, there was one analyzer for measuring the concentrations, except for $\mathrm{NO}$ and $\mathrm{NO}_{\mathrm{x}}$ which were measured with one instrument. The response times of the analyzers were about $30 \mathrm{~s}$, so when sampling a new height, a flush time of about $30 \mathrm{~s}$ was needed. The sample line system and instrumentation at the station is designed for measuring accurately the concentration profiles which then degrade the temporal coverage of the results for the separate measurement heights. The combined response and flush time set the signal recording time step to $1 \mathrm{~min}$ and the overall time spacing of the data per measurement height to $6 \mathrm{~min}$. In general, the averaging times were different for different analyzers. Exact averaging times cannot be given for every analyzer because of the combination of averaging caused by flushing of sample volumes, signal averaging and "sample measurement - reference measurement sequencing" of an analyzer vs. the switching cycle of sample heights in the tower. For the $\mathrm{CO}_{2}$ analyzer, each $1 \mathrm{~min}$ signal is approximately a $30 \mathrm{~s}$ average; for the $\mathrm{CO}$ analyzer, each $1 \mathrm{~min}$ signal is approximately a $1 \mathrm{~min}$ average. The signal standard deviations of the $\mathrm{CO}_{2}$ and the $\mathrm{CO}$ 
analyzers were $0.04 \mathrm{ppm}$ and $6 \mathrm{ppb}$, respectively, when sampling calibration gas. These are the estimates for the precision of any 1 min value.

VOCs were measured with Proton Transfer Reaction Mass Spectrometers (PTR-MS, Ionicon Analytik, Innsbruck, Austria; e.g., Hewitt et al., 2003) at two locations: one at the SMEAR II main building with an inlet above the roof at about $10 \mathrm{~m}$ above ground level and the other in the REA cottage with the inlet above canopy at about $16 \mathrm{~m}$ above ground level at the REA tower. The PTR-MS instrument measures charged VOCs at a given mass that was assigned to the VOCs that likely dominated each signal. The assignment of massto-charge ratios $(m / z)$ to VOCs and the measurement setup are described by Taipale et al. (2008). Usually, $m / z=69$ is assigned to the biogenic VOCs isoprene and 2-Methyl-3buten-2-ol (MBO), but, in this case, $m / z=69$ was assigned to furan, which is associated with burning processes (de Gouw and Warneke, 2007). The VOC measurements were sampled every $1 \mathrm{~min}$.

An Aerodyne Aerosol Mass Spectrometer (AMS) (e.g., Jayne et al., 2000; Jimenez et al., 2003; Drewnick et al., 2005) was used for measuring the concentrations of ammonium $\left(\mathrm{NH}_{4}^{+}\right)$, sulfate $\left(\mathrm{SO}_{4}^{2-}\right)$, nitrate $\left(\mathrm{NO}_{3}^{-}\right)$, chloride $\left(\mathrm{Cl}^{-}\right)$ and organics in particles with $D_{\mathrm{p}}<600 \mathrm{~nm}$. The AMS was located in the SMEAR II main building, and it took its sample from the same inlet as the PTR-MS, above the roof at about $10 \mathrm{~m}$ above ground level. The AMS measurements were taken every $5 \mathrm{~min}$.

In the aerosol cottage, particle number size distributions for particles of 3-1000 $\mathrm{nm}$ in diameter were measured with a custom-made twin differential mobility particle sizer (TDMPS) system (Aalto et al., 2001) and a TSI aerodynamic particle sizer (APS) in the aerodynamic diameter size range of $0.53-20 \mu \mathrm{m}$. In the overlapping range of the TDMPS and the APS, the number concentrations from the TDMPS were used up to $700 \mathrm{~nm}$. Data were collected every $10 \mathrm{~min}$. A Neutral cluster and Air Ion Spectrometer (NAIS) was used to measure the mobility and size distributions of atmospheric ions and neutral clusters in the size range of $0.8-47 \mathrm{~nm}$ (e.g., Manninen et al., 2009; Asmi et al., 2009) for the first time in a wildfire smoke plume. The NAIS measurements were taken every 2 min.

The aerosol optical measurements at SMEAR II were described by Virkkula et al. (2011). In short, total scattering coefficients $\left(\sigma_{\mathrm{sp}}\right)$ and backscattering coefficients $\left(\sigma_{\mathrm{bsp}}\right)$ were measured with a TSI $3 \lambda$ nephelometer, averaged over a $5 \mathrm{~min}$ period. A Magee Scientific $7 \lambda$ Aethalometer (AE-31) was used for measuring light absorption, also at a $5 \mathrm{~min}$ averaging time. The absorption coefficient $\left(\sigma_{\mathrm{ap}}\right)$ was calculated from the aethalometer and nephelometer data using the algorithm by Arnott et al. (2005).

Aerosol optical depth was measured with a Cimel CE-318 sunphotometer in a tower about $100 \mathrm{~m}$ east of the aerosol cottage (Fig. 1), above the canopy level. The sunphotometer made one instantaneous measurement every $15 \mathrm{~min}$. In the same tower, the light absorption coefficient at a wavelength $(\lambda)$ of $637 \mathrm{~nm}$ was measured with a Multi-Angle Absorption Photometer (MAAP). The MAAP reports the absorption coefficient as black carbon concentrations using the mass absorption coefficient of $6.6 \mathrm{~m}^{2} \mathrm{~g}^{-1}$. MAAP measurements were available every $1 \mathrm{~min}$.

In addition to the SMEAR II measurements, meteorological instrumentation was installed on top of poles within and around the area to be burned (hereafter called stations). The poles were prepared by cutting the branches of five trees that were left standing in the slash. Four stations were outside the burning area, and one was within it (Fig. 1a). The distances of the stations 1,2,3 and 4 from the perimeter of the burn area were $10,8,9$ and $6 \mathrm{~m}$, respectively. In situ meteorological instrumentation (Vaisala WTX510) was deployed on the burn perimeter, and a sonic anemometer (Applied Technologies, Inc. (ATI) Sx-Probe) and Vaisala GMP-343 $\mathrm{CO}_{2}$ sensor were placed within the burn area on the area on the top of a pole at about $12 \mathrm{~m}$ in height. Total heat flux, $Q$, including radiative heat flux, was measured at $1 \mathrm{~m}$ above the surface with a water-cooled Hukseflux SBG01 sensor. Fine-wire thermocouples (Omega, 5SC-TT-E-40-36, Type-E) were mounted along the pole to measure near-surface plume temperatures.

\subsubsection{Mobile measurements}

Ground-level dispersion of aerosols and gases was measured in Sniffer from the Metropolia University of Applied Sciences, Helsinki (Pirjola et al., 2004, 2006). Sniffer was driven along the surrounding forest roads and stopped at several locations for some minutes. Sampling occurred above the windshield of the van at $2.4 \mathrm{~m}$ altitude. Particle number concentration and size distribution were measured by an Electrical Low Pressure Impactor (ELPI, Dekati Ltd) at a flow rate of $10 \mathrm{~L} \mathrm{~min}^{-1}$ (Keskinen et al., 1992). ELPI was equipped with a filter stage (Marjamäki et al., 2002) and a stage to enhance the particle size resolution for nanoparticles (YliOjanperä et al., 2010). The ELPI classifies particles in the size range of $7 \mathrm{~nm}-10 \mu \mathrm{m}$ (aerodynamic diameter) into 12 classes with samples every $1 \mathrm{~s}$. Sniffer also monitored concentrations of $\mathrm{CO}, \mathrm{NO}, \mathrm{NO}_{2}$ and $\mathrm{CO}_{2}$ at $1 \mathrm{~s}$ intervals. Furthermore, $\mathrm{PM}_{2.5}$ and $\mathrm{PM}_{10}$ were recorded by two TSI DustTrak aerosol monitors. The DustTraks measure light scattering, but they were not specifically calibrated for smoke aerosol. A weather station on the roof of Sniffer at $2.9 \mathrm{~m}$ height provided meteorological parameters (temperature, relative humidity, wind speed and wind direction). A global positioning system (GPS) was used to record the van's speed and the driving route.

In addition to Sniffer, the dispersion at ground level was measured by students walking around the area with three portable TSI model 3007 condensation particle counters (CPCs) and GPS receivers. There were three different routes at three distances from the burning area. The CPCs used in the nearest two routes were equipped with diluters because, 
according to the manual, the model 3007 CPC measures concentrations up to $10^{5} \mathrm{~cm}^{-3}$. The diluters were calibrated afterwards and a flow rate of $0.7 \mathrm{~L} \mathrm{~min}^{-1}$ in the $3007 \mathrm{CPC}$ produced a dilution ratio of about 0.32 . Thus, the concentrations from the two nearest routes were divided by 0.32 , resulting in the upper limit of the concentration range increasing to about $3 \times 10^{5} \mathrm{~cm}^{-3}$.

Vertical and horizontal dispersion were measured with instruments installed in a Cessna 172 research aircraft (Schobesberger et al., 2013; Virkkula et al., 2013). There were three CPCs for measuring particle number concentrations at three cutoffs $(3,6$ and $10 \mathrm{~nm})$. The $3 \mathrm{~nm}$ cutoff was with a TSI model 3776 CPC. The other two were TSI model 3772 CPCs equipped with 1:10 diluters and set up for cutoff sizes of $6 \mathrm{~nm}$ and $10 \mathrm{~nm}$. In the present article, the discussion of particle number concentrations is based on the model 3776 CPC only. The scattering coefficient $\left(\sigma_{\mathrm{sp}}\right)$ at $\lambda=545 \mathrm{~nm}$ was measured with a Radiance Research model 903 nephelometer, and the absorption coefficient $\left(\sigma_{\mathrm{ap}}\right)$ was measured with a Radiance Research 3- $\lambda$ Particle Soot Absorption Photometer (PSAP) at $\lambda=467 \mathrm{~nm}, 530 \mathrm{~nm}$ and $660 \mathrm{~nm}$. A LI-COR LI-840 measured $\mathrm{CO}_{2}$ concentrations. The data were saved at $1 \mathrm{~Hz}$ frequency. The scattering and absorption coefficients will be discussed in the companion paper (Virkkula et al., 2013).

\subsubsection{Soil and flux measurements}

The changes in soil physical, chemical and biological environment were monitored with a long-term perspective, as similar high-frequency instrumentation described above for atmospheric aerosol and trace gas concentrations are not available for the soil parameters. Also, although the soil conditions do change rapidly during and after the fire, many of the biological processes and responses to changing conditions have a time lag and therefore require several years of monitoring. These slowly changing responses were expected, for instance in soil $\mathrm{pH}$ and the concentrations of available nitrogen, as well as soil greenhouse gas fluxes.

Long-term ecological measurements were begun in the mature forest in 2008 before the clear-cutting and partial burning. The measurements were performed at three sites: (1) in the area that was later clear-cut, (2) in the area that was later clear-cut and also burned and (3) in an area that remained as a mature forest. These measurements comprised automatic soil temperature and moisture measurements in the organic layer and in the A and B mineral soil horizons, manual measurements of the heights of soil organic layers, and the total carbon and nitrogen content, as well as available nitrogen species and $\mathrm{pH}$ in organic and mineral soil horizons. The soil horizon is a layer parallel to the soil surface, whose physical characteristics differ from the layers above and beneath. The measurement campaign ended in late 2011, two and a half years after the burn.
The long-term effects of the burning of slash on the $\mathrm{CO}_{2}$ and $\mathrm{CH}_{4}$ fluxes from the soil were quantified by manual chamber measurements from the burned area every two weeks, together with the corresponding measurements from the clear-cut and a control forest (Kulmala et al., 2014). The fluxes were measured every two weeks from early May to the end of November for one year before and for three years after the treatment. The flux measurements were performed by placing a chamber on a collar inserted into the soil to an approximate depth of $5 \mathrm{~cm}$. Eleven collars were inserted for $\mathrm{CO}_{2}$ measurement and eight collars were inserted for $\mathrm{CH}_{4}$ measurement at each site, and one closure took 4 min for $\mathrm{CO}_{2}$ and $35 \mathrm{~min}$ for $\mathrm{CH}_{4}$, as described in detail by Kulmala et al. (2014) and Pihlatie et al. (2013). During 2008-2010, $\mathrm{CO}_{2}$ fluxes at each site were also measured using an automatic chamber described in detail by Kulmala et al. (2010). We approximated the cumulative release of $\mathrm{CO}_{2}$ at each site after the treatments by interpolating the effluxes from each treatment separately between the days.

The emission of forest-floor VOCs was measured at the burn site twice before (23-24 July and 1-2 October 2008) and three times after the burning (14-15 July 2009, 15-16 September 2009 and 24-25 October 2010). The VOC fluxes were measured on five permanently installed collars with a manual steady-state chamber system. The VOC sampling and analysis method is described by Aaltonen et al. (2011).

\subsection{Formulas used for data processing}

By using the measurements in the $12 \mathrm{~m}$ pole within the burning area, the turbulent sensible heat flux was calculated from the covariance of the vertical velocity and sonic temperature perturbation as

$H_{\mathrm{s}}=\rho c_{\mathrm{p}} \overline{w^{\prime} T^{\prime}}$,

where $\rho$ is the air density, assumed to be constant, and $c_{p}$ is the heat capacity of air at constant pressure. The turbulent kinetic energy (TKE) is calculated from the sum of the velocity variances:

$\mathrm{TKE}=\frac{1}{2}\left(\rho_{u}^{2}+\rho_{v}^{2}+\rho_{w}^{2}\right)$.

In the smoke plume, concentrations of trace gases and aerosols were elevated. The concentration of trace gas $\mathrm{X}$ above the background is defined as the excess concentration and denoted as $\Delta \mathrm{X}$. The concentrations of several trace gases vary also smoothly during the day due to biological processes such as photosynthesis, so the background was not taken as a constant value for the whole day. Instead, at every time step $t$, all concentrations of a trace gas $\mathrm{X}$ measured in the time range of [ $t-30 \mathrm{~min}, t+30 \mathrm{~min}]$ were taken into account, and the background was the lowest concentration of $X$ during this time. This was applied both for the data obtained from the mast and for the PTR-MS data. For the trace gases measured from the mast at alternating altitudes, the background 
was calculated without taking the altitude into account (i.e., by considering the time series as if it had been measured at one altitude only).

Trace gas emission from biomass burning can be expressed as an emission factor (EF), which signifies the emitted mass of trace gas $\mathrm{X}$ divided by the burned dry biomass, or as emission ratios $(E R)$ that relate the emission of the species $\mathrm{X}$ to that of a reference species (e.g., Andreae and Merlet, 2001; Simpson et al., 2011). When CO is used as the reference species, the emission ratio is

$E R_{\mathrm{X} / \mathrm{CO}}=\frac{\Delta \mathrm{X}}{\Delta \mathrm{CO}}$.

If there are several simultaneous $\Delta \mathrm{X}$ and $\Delta \mathrm{CO}$ values, the emission ratio can also be calculated by fitting the line $\Delta \mathrm{X}=$ $E R_{\mathrm{X} / \mathrm{CO}} \Delta \mathrm{CO}$ with linear regression with the offset forced to zero (e.g., Yokelson et al., 1999; Simpson et al., 2011).

The aerosol number size distributions were used for calculating volume size distributions and the integrated mass concentrations were calculated by assuming a density of $1.5 \mathrm{~g} \mathrm{~cm}^{-3}$. Three to five lognormal modes were fitted to the data up to $10 \mu \mathrm{m}$. The fitting yields the modal parameters (geometric mean diameter $\left(D_{\mathrm{g}}\right)$, geometric standard deviation $\left(\sigma_{\mathrm{g}}\right)$, and number or volume concentration of the mode).

The in situ aerosol optical data were analyzed as discussed in Virkkula et al. (2011). Here we calculated three intensive aerosol optical properties: the single-scattering albedo $\left(\omega_{0}\right)$, the Ångström exponent of scattering $\left(\alpha_{\mathrm{sp}}\right)$ and the backscatter fraction (b).

$\omega_{0}=\frac{\sigma_{\mathrm{sp}}}{\sigma_{\mathrm{sp}}+\sigma_{\mathrm{ap}}}$

is a measure of the darkness of aerosols; for purely scattering aerosols, it equals 1 . For freshly generated pure Black Carbon (BC) $\omega_{0}$ has been measured to be $0.2 \pm 0.1$ (e.g., Bond and Bergstrom, 2006; Mikhailov et al., 2006; Cross et al., 2010; Bond et al., 2013). The Ångström exponent of scattering $\alpha_{\mathrm{sp}}$ describes the wavelength dependency of scattering, and it was calculated for the nephelometer wavelength range by taking the logarithm of scattering coefficients and the respective wavelengths and fitting the data line to the line

$\ln \left(\sigma_{\mathrm{sp}}\right)=-\alpha_{\mathrm{sp}} \ln (\lambda)+C$,

where $C$ is a constant not relevant in this study. In general, large values $\left(\alpha_{\mathrm{sp}}>2\right)$ indicate the dominance of small particles, and small values $\left(\alpha_{\mathrm{sp}}<1\right)$ indicate the dominance of large particles. This relationship is not unambiguous, however (e.g., Schuster et al., 2006; Virkkula et al., 2011).

The backscatter fraction

$b=\frac{\sigma_{\mathrm{bsp}}}{\sigma_{\mathrm{sp}}}$,

where $\sigma_{\mathrm{bsp}}$ is the backscattering coefficient, is a measure related to the angular distribution of light scattered by aerosol particles. From $b$, it is possible to estimate the average upscatter fraction $\beta$ and the aerosol asymmetry parameter, which are the key properties controlling the aerosol direct radiative forcing (e.g., Andrews et al., 2006). In general, larger particles scatter less light backwards than small particles so the size relationship of $b$ is qualitatively similar to that of $\alpha_{\mathrm{sp}}$.

The radiative forcing efficiency $(\Delta F / \delta)$, i.e., aerosol forcing per unit optical depth $(\delta)$, was calculated from

$$
\begin{aligned}
& \frac{\Delta F}{\delta}=-D S_{0} T_{\mathrm{at}}^{2}\left(1-A_{\mathrm{c}}\right) \omega_{0} \beta \\
& \left\{\left(1-R_{\mathrm{S}}\right)^{2}-\left(\frac{2 R_{\mathrm{s}}}{\beta}\right)\left[\left(\frac{1}{\omega_{0}}\right)-1\right]\right\},
\end{aligned}
$$

where $D$ is the fractional day length, $S_{\mathrm{o}}$ is the solar constant, $T_{\text {at }}$ is the atmospheric transmission, $A_{\mathrm{c}}$ is the fractional cloud amount, $R_{\mathrm{S}}$ is the surface reflectance, and $\beta$ is the average upscatter fraction calculated from $b$. If the non-aerosol-related factors are kept constant and if it is assumed that $\beta$ has no zenith angle dependence, this formula can be used for assessing the intrinsic radiative forcing efficiency by aerosols (e.g., Sheridan and Ogren, 1999; Delene and Ogren, 2002). The constants used were $D=0.5$, $S_{\mathrm{o}}=1370 \mathrm{~W} \mathrm{~m}^{-2}, T_{\mathrm{at}}=0.76, A_{\mathrm{c}}=0.6$, and $R_{\mathrm{S}}=0.15$ as suggested by Haywood and Shine (1995), and $\beta$ was calculated from $\beta=0.817+1.8495 b-2.9682 b^{2}$ (Delene and Ogren, 2002). The value of $R_{\mathrm{S}}=0.85$ was used to assess the effect of the aerosols above snow surfaces.

\section{Results and discussion}

\subsection{General description of the burning}

Whenever prescribed fires are conducted, parameters affecting fire weather, such as biomass moisture, temperature, relative humidity, wind speed and rainfall should be measured and documented prior to and during the burning operation, as recommended by Alexander (2006). The measurement setup was ready at the beginning of May 2009, waiting for the proper conditions. For our experiment the required conditions were: (1) wind direction was to be in the range of $175^{\circ}-$ $215^{\circ}$ to blow smoke to our ground-based instrumentation, (2) wind speed had to be less than $5 \mathrm{~m} \mathrm{~s}^{-1}$ to keep the fire under control as suggested by the Finnish handbook of prescribed burns (Lemberg and Puttonen, 2002), (3) soil had to be dry enough to burn properly, and (4) the sky was to be clear so that the smoke plume (i.e., the visible column of smoke) could be followed with the aircraft and possibly even from satellites. Fulfilment of requirement 3 was assessed from the forest fire warnings issued by the Finnish Meteorological Institute. In Finland, forest fire danger is assessed by the Forest Fire Index (FFI), which is calculated from soil moisture, so that for very wet conditions FFI $<2$ and for very dry conditions FFI $=6.0$ (Vajda et al., 2013). 
Table 1. Estimated amount of burned organic material during the experiment. s.e. = standard error of the estimate.

\begin{tabular}{|c|c|c|c|c|c|c|c|c|}
\hline & $\begin{array}{l}\text { Mass } \\
(\mathrm{kg})\end{array}$ & \pm s.e. & $\begin{array}{c}\text { Mass/area } \\
\left(\mathrm{kg} \mathrm{ha}^{-1}\right)\end{array}$ & \pm s.e. & $\begin{array}{l}\text { Carbon } \\
(\mathrm{kg})\end{array}$ & \pm s.e. & $\begin{array}{l}\text { Carbon/area } \\
\left(\mathrm{kg} \mathrm{ha}^{-1}\right)\end{array}$ & \pm s.e. \\
\hline Tree biomass & 30700 & & 38030 & & 15400 & & 19080 & \\
\hline Surface vegetation & 1850 & & 2300 & & 930 & & 1150 & \\
\hline Organic soil layer & 14200 & & 17600 & & 7100 & & 8800 & \\
\hline Sum & 46800 & \pm 10900 & 58000 & \pm 13500 & 23400 & \pm 5500 & 29000 & \pm 6800 \\
\hline
\end{tabular}

The last rain before the burning day was on 20 June, and on 25 June fuel volumetric moisture had decreased below $0.2 \mathrm{~m}^{3} \mathrm{~m}^{-3}$ and FFI increased above 4 in the scale from 1 to 6. On the morning of 26 June, a handheld smoke signal was ignited soon after 07:00 Eastern European Time (EET = UTC $+2 \mathrm{~h}$ ) in order to make the final decision of whether to start the fire. Wind was blowing from the right direction, the sky was clear, and soil moisture was $0.18 \mathrm{~kg} \mathrm{~kg}^{-1}$, so FFI was 4.2. Relative humidity and temperature at $4.2 \mathrm{~m}$ above ground was $56 \%$ and $19^{\circ} \mathrm{C}$, respectively. The conditions were acceptable, so the area was set on fire at 07:45 EET. (All times presented below will be in EET, not in Eastern European Summer Time.)

The burning was performed against the wind as a backing burn; first the fire was ignited against the wind and then ignition slowly proceeded in both directions (Fig. 1a). The idea was to slowly burn the edges of the site until a horseshoelike shape was achieved and more than half of the area was burned (Fig. 2a). This phase of our experiment took about $110 \mathrm{~min}$. Then, the edges were rapidly ignited in both directions so that the edges of the site were enclosed with the fire (Fig. 2b). Thereafter, the fire proceeded rapidly downwind, and flaming was over within about $25 \mathrm{~min}$. Flame height was not measured, but we estimate that during the flaming phase, it was approximately 1-3 $\mathrm{m}$ (from the photographs in Fig. 2a-f). Flame lengths varied from about $1 \mathrm{~m}$ during backing fires along the burn plot edge to $\sim 5-10 \mathrm{~m}$ during heading fires. While the rate of fire spread (ROS) was not measured during the experiment, estimates were made in the field. About $50 \%$ of the firing operations consisted of backing fires with an estimated ROS $\sim 0.01 \mathrm{~m} \mathrm{~s}^{-1}$ while the remaining ignitions were made using head fires with an average ROS of $\sim 0.2 \mathrm{~m} \mathrm{~s}^{-1}$. The flaming or active burning was over at 10:00 EET, and there was only a little visible smoke at 13:00 EET. These times will be shown in the figures below as the indicators of the flaming and smoldering phases of the burning, although the ends of both periods were not well defined. There were flames in some parts of the area while most of it was already smoldering, and smoldering biomass does not always emit visible smoke.

After the burning, the amount of burned organic material was estimated as described above (Sect. 2.2). The amount of unburned wood was $30700 \mathrm{~kg}$. The burned area was approximately 0.81 ha, so the amount of burned wood

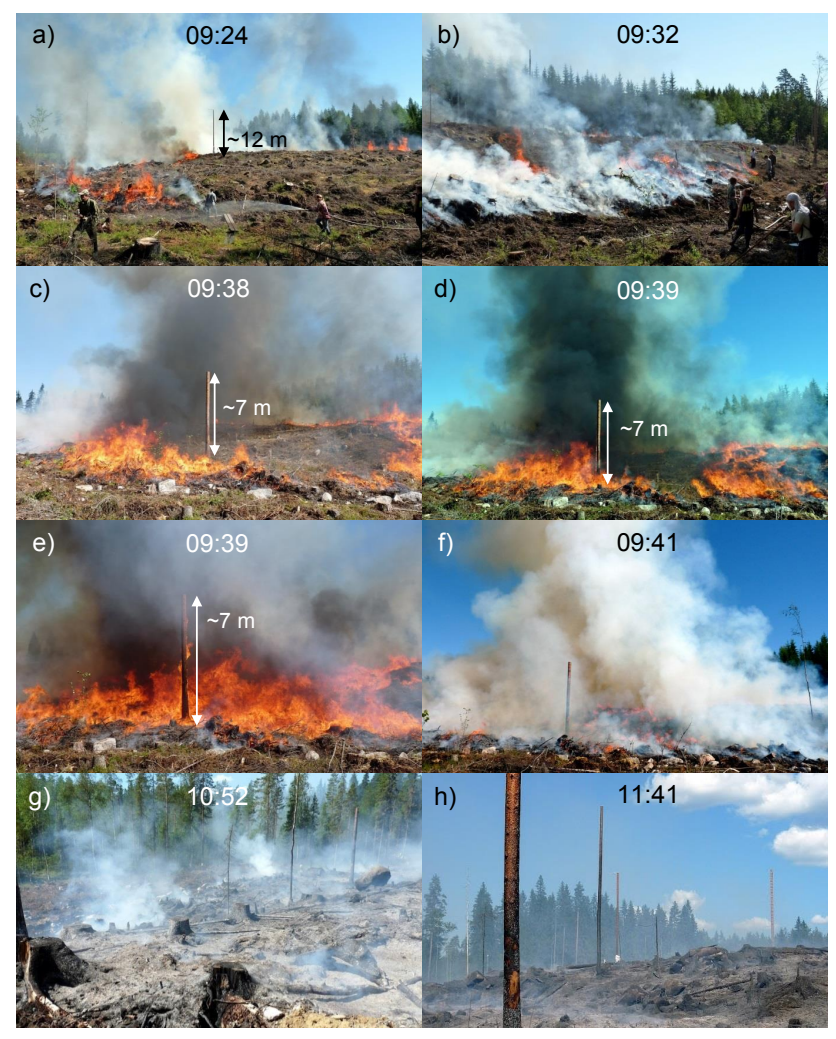

Fig. 2. Photographs of the burn area during the flaming phase (a-f) and the smoldering phase $(\mathbf{g}, \mathbf{h})$.

biomass was about $38030 \mathrm{~kg} \mathrm{ha}^{-1}$. All the surface vegetation, $1850 \mathrm{~kg}\left(2300 \mathrm{~kg} \mathrm{ha}^{-1}\right)$, was burned. The mass of burned organic material in the organic soil layer was $14200 \mathrm{~kg}\left(17600 \mathrm{~kg} \mathrm{ha}^{-1}\right)$. The total amount of burned organic material $\left(46800 \mathrm{~kg}, 58000 \mathrm{~kg} \mathrm{ha}^{-1}\right.$ ) was calculated as a sum of burned tree biomass, surface vegetation and organic soil layer (Table 1). The burned biomass was strongly dominated by slash (non-commercial wood), and the roundwood material consisted of treetops, with a diameter of $7 \mathrm{~cm}$ or less, and branches typically smaller than $5 \mathrm{~cm}$ in diameter. The mass portion of the needle foliage from the total burned biomass was $37 \%$. Schlesinger (1997) noted that the carbon content of biomass is generally between $45 \%$ and $50 \%$ (by oven-dry mass). Table 1 also presents an estimated amount of carbon released by multiplying the biomass by 0.5 . 
Table 2. Measurements made during the prescribed fire experiment, the instrument type, location of the instrument, and the responsible institute.

\begin{tabular}{|c|c|c|c|}
\hline Quantity & Instrument & Location & Institute \\
\hline \multicolumn{4}{|c|}{ Meteorology } \\
\hline Heat flux & Hukseflux SBG01 & mast within the burn area & SJSU (San Jose State University) \\
\hline \multirow[t]{3}{*}{ Wind } & 2-D anemometers & SMEAR II mast, several altitudes & UHEL (University of Helsinki) \\
\hline & Vaisala WXT 520 & small masts around burn area & FMI (Finnish Meteorological Institute) \\
\hline & 3-D sonic anemometer, ATI, Sx probe & mast within the burn area & SJSU \\
\hline $\mathrm{CO}_{2}$ & URAS 4 & $\begin{array}{l}\text { SMEAR II mast, several altitudes } \\
\text { mast within the burn area }\end{array}$ & $\begin{array}{l}\text { UHEL } \\
\text { SJSU }\end{array}$ \\
\hline $\mathrm{CO}$ & Horiba APMA & SMEAR II mast, several altitudes & UHEL \\
\hline $\mathrm{NO}_{\mathrm{x}}$ & TEI 42CTL & SMEAR II mast, several altitudes & UHEL \\
\hline $\mathrm{O}_{3}$ & TEI 49C & SMEAR II mast, several altitudes & UHEL \\
\hline VOCs & Proton Transfer Reaction Mass Spectrometer & REA cottage & UHEL \\
\hline & (PTR-MS) & SMEAR II, new part & UHEL \\
\hline \multicolumn{4}{|c|}{ Aerosol physical properties } \\
\hline \multicolumn{4}{|l|}{ Size distribution } \\
\hline$D_{\mathrm{p}}: 3-1000 \mathrm{~nm}$ & differential mobility particle sizer & Aerosol cottage & UHEL \\
\hline$D_{\mathrm{p}}: 0.5-10 \mu \mathrm{m}$ & aerodynamic particle sizer & Aerosol cottage & UHEL \\
\hline$D_{p}: 0.4-40 \mathrm{~nm}$ & Neutral cluster and Air Ion Spectrometer (NAIS) & Aerosol cottage & UHEL \\
\hline Scattering coefficient & $3-\lambda$ nephelometer & Aerosol cottage & UHEL \\
\hline Absorption coefficient & $7-\lambda$ aethalometer & Aerosol cottage & UHEL \\
\hline & Multi-Angle Absorption Photometer (MAAP) & AODTWR & FMI \\
\hline Aerosol optical depth & Sunphotometer & AODTWR & FMI \\
\hline \multicolumn{4}{|c|}{ Aerosol chemical composition } \\
\hline $\mathrm{NO}_{3}^{-}$ & Aerosol Mass Spectrometer (AMS) & SMEAR II, new part & UHEL \\
\hline $\mathrm{SO}_{4}^{2-}$ & AMS & SMEAR II, new part & UHEL \\
\hline $\mathrm{NH}_{4}^{+}$ & AMS & SMEAR II, new part & UHEL \\
\hline $\mathrm{Cl}^{-}$ & AMS & SMEAR II, new part & UHEL \\
\hline Organics & AMS & SMEAR II, new part & UHEL \\
\hline \multicolumn{4}{|c|}{$\begin{array}{l}\text { Mobile measurements } \\
\text { On ground }\end{array}$} \\
\hline Number concentration & Electric Low Pressure Impactor (ELPI) & Sniffer van & MUAS (Metropolia University of Applied Sciences) \\
\hline Size distribution & & Sniffer van & MUAS \\
\hline $\mathrm{CO}_{2}$ & & Sniffer van & MUAS \\
\hline $\mathrm{CO}$ & & Sniffer van & MUAS \\
\hline $\mathrm{NO}_{\mathrm{x}}$ & & Sniffer van & MUAS \\
\hline \multicolumn{4}{|c|}{ Airborne } \\
\hline Number concentration & 2 TSI Model 3762 and 1 model 3772 CPC & Cessna 172 & UHEL \\
\hline Scattering coefficient & Radiance Research, $1-\lambda$ nephelometer, $545 \mathrm{~nm}$ & Cessna 172 & UHEL \\
\hline Absorption coefficient & Radiance Research, 3- $\lambda$ PSAP & Cessna 172 & UHEL \\
\hline $\mathrm{CO}_{2}$ & LI-COR LI-840 & Cessna 172 & UHEL \\
\hline \multicolumn{4}{|c|}{ Soil measurements } \\
\hline Temperature & iButtons, PT100 & Burned and reference area & UHEL \\
\hline Moisture & ThetaProbe & Burned and reference area & UHEL \\
\hline $\mathrm{pH}$ & & Burned and reference area & UHEL \\
\hline $\mathrm{C} / \mathrm{N}$-ratio & & Burned and reference area & UHEL \\
\hline Nitrogen compounds & & Burned and reference area & UHEL \\
\hline $\mathrm{CO}_{2}$ efflux & Vaisala GMP343 & Burned and reference area & UHEL \\
\hline $\mathrm{CH}_{4}$ flux & Agilent Gas Chromatograph model 7890A & Burned and reference area & UHEL \\
\hline VOC flux & $\begin{array}{l}\text { Tenax-Carbopack-B + GC-MS } \\
\text { (Gas Chromatograph-Mass Spectrometer) }\end{array}$ & Burned area & UHEL \\
\hline
\end{tabular}

\subsection{Winds}

Most of the smoke ascended almost vertically, as seen from the aerial photographs taken during the flaming phase of the experiment (Fig. 1), indicating that wind speed was not high and no strong temperature inversion was present to inhibit the rising smoke. That the wind speed was low is also shown by measurements at the SMEAR II $73 \mathrm{~m}$ mast. At the ignition time, wind speed was $<2 \mathrm{~m} \mathrm{~s}^{-1}$ at all altitudes of the tower, but it increased to $2-4 \mathrm{~m} \mathrm{~s}^{-1}$ during the morning (Fig. 3a). 
a)

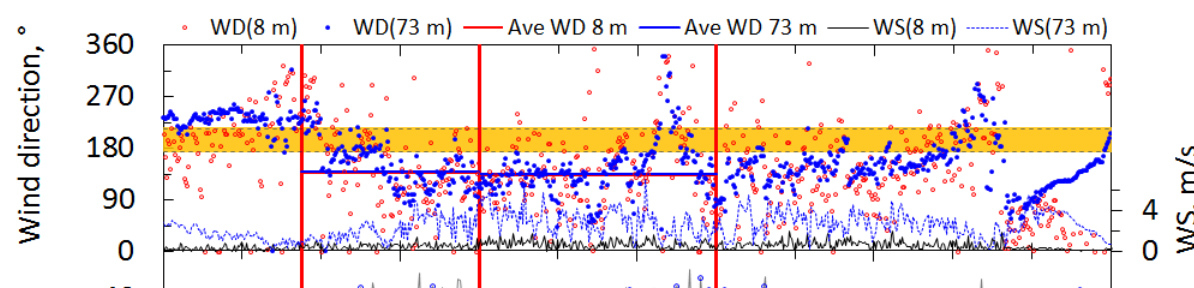

b)

응

40

03

c)

응

d)

응

e)

$\frac{2}{2}$

f)

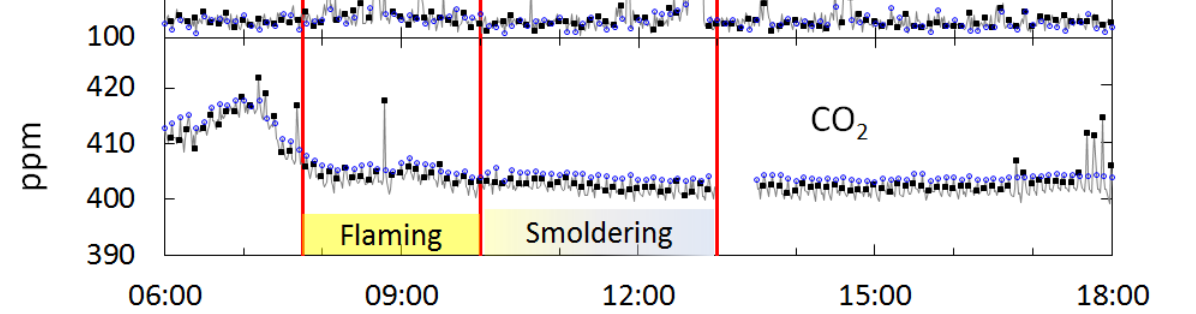

Fig. 3. Selected data obtained from the SMEAR II mast during the burning day at a 1 min time resolution. (a) Wind direction and speed at two altitudes: $8 \mathrm{~m}$ and $74 \mathrm{~m}$ above ground level. The dark yellow shading indicates the wind direction sector that would bring smoke from the fire to SMEAR II. (b-f) Concentrations of selected trace gases measured at all altitudes (grey line) and at the lowest and the highest trace gas sampling levels, that is $4 \mathrm{~m}$ and $67 \mathrm{~m}$ above ground (black square and blue circle, respectively). The temporal spacing of the trace gas data at each height is $6 \mathrm{~min}$. The red vertical lines indicate the start and end of the flaming and clear smoldering phases.

After ignition, the wind direction turned from southwesterly to southeasterly. On average, the directional shear between the $8.4 \mathrm{~m}$ and $73 \mathrm{~m}$ levels was small: the average wind direction was $138^{\circ}$ and $134^{\circ}$ at the $8.4 \mathrm{~m}$ level and $140^{\circ}$ and $136^{\circ}$ at the $73 \mathrm{~m}$ level during the flaming and smoldering phases, respectively. The average ( \pm standard deviation) wind speed was $0.55 \pm 0.26 \mathrm{~m} \mathrm{~s}^{-1}$ and $0.74 \pm 0.38 \mathrm{~m} \mathrm{~s}^{-1}$ at the $8.4 \mathrm{~m} \mathrm{level} \mathrm{and} 2.2 \pm 1.1 \mathrm{~m} \mathrm{~s}^{-1}$ and $3.0 \pm 1.3 \mathrm{~m} \mathrm{~s}^{-1}$ at the $73 \mathrm{~m}$ level during the flaming and smoldering phases, respectively. The wind directions at the highest and lowest levels started to diverge gradually after 17:00 EET. The $8.4 \mathrm{~m}$ wind weakened and turned to the east-northeast (Fig. 3a), so the observed $\mathrm{O}_{3}$ decrease and $\mathrm{CO}_{2}$ increase at this level (Fig. 3b, f) were not related to possible emissions from the smoldering ground at the burned site, nor were any of the SMEAR II ground-based aerosol measurements.

Measurements from the sonic anemometer at the top of the $12 \mathrm{~m}$ pole within the burning area (Fig. 4) show that both the wind direction and wind speed varied considerably more than at the SMEAR II mast. This greater variability is explainable both by the forest around the high mast and by fire-induced winds within the open burning area. During the flaming period, the average wind direction and speed at the top of the pole were $189^{\circ}$ and $2.5 \pm 1.1 \mathrm{~m} \mathrm{~s}^{-1}$ (Fig. $4 \mathrm{f}$, g) so the wind speed was slightly higher than at the top of the $73 \mathrm{~m}$ mast during the flaming period. The increased variability in wind 
a)

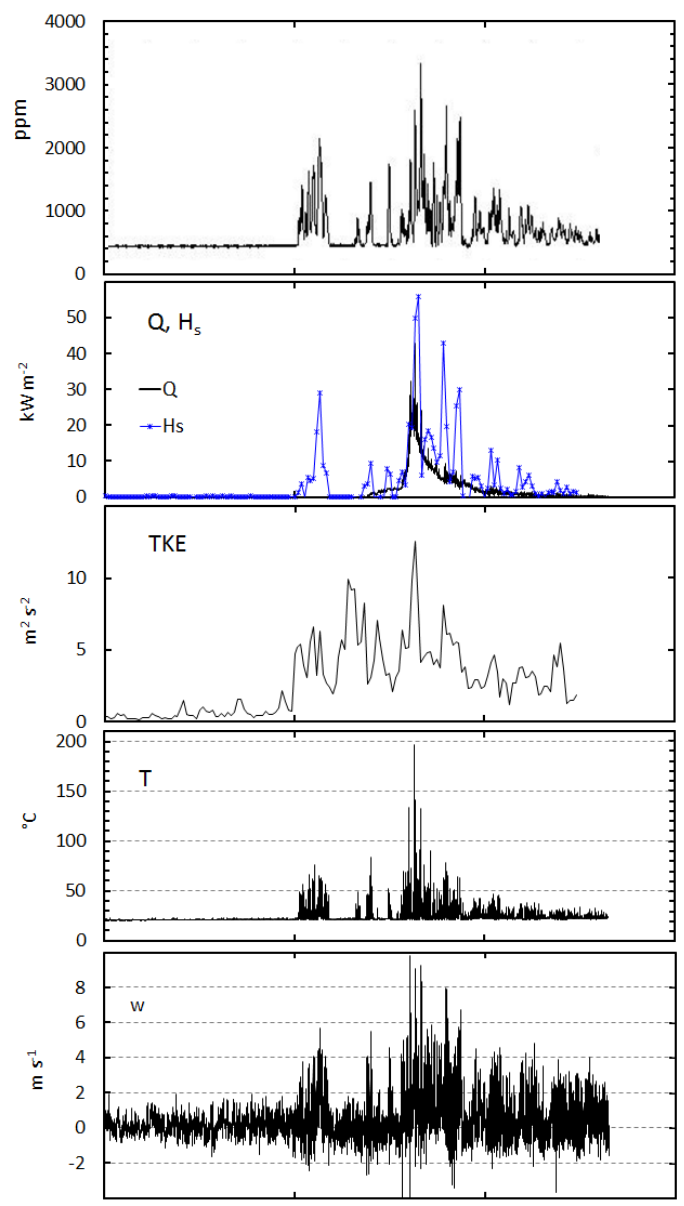

d)

e)

f)

g)

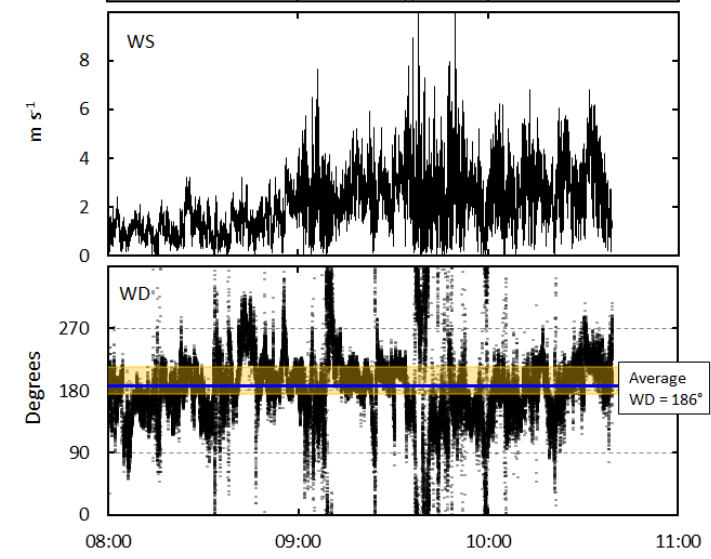

Fig. 4. Observations within the burning area during the flaming phase. (a) $\mathrm{CO}_{2}$ concentrations, (b) heat flux (Q), turbulent sensible heat flux (Hs), (c) turbulent kinetic energy (TKE), (d) temperature $(T),(\mathbf{e})$ vertical flow velocity $(w)$, (f) horizontal wind speed (WS), and (g) wind direction (WD) at direction (WD) at $12 \mathrm{~m}$ above ground level. The 3-D wind data are at $10 \mathrm{~Hz}$, time resolution. The yellow shading indicates the wind direction sector that would bring smoke from the fire to SMEAR II. speed and direction is caused by fire-atmosphere interactions that occur near the fire front (defined as the leading edge of the flames) and within the near-surface plume (Clements et al., 2008). An increase in wind speed has been observed to occur at the fire front or during fire-front passage during both wind-driven grass fires (Clements et al., 2007) and crown fires (Coen et al., 2004). Maximum updraft vertical velocities and maximum temperatures also indicate the location of the fire front (Clements et al., 2007).

Although the small-scale features of the fire front and variability in its intensity cannot be resolved by the vertical velocity and plume temperature (Fig. 4d, e), the crude, nearsurface properties of the atmosphere surrounding the combustion zone can be quantified. The fire front advanced from the northeast and northwest corners, south and around to the southern edge of the clear-cut area. The fire burned as a head fire from the north to the south and through the center of the burn area. While the flame front passed the mast only once, the plume from other burning areas passed the mast several times, which is indicated by sharp increases in $\mathrm{CO}_{2}$ concentration, positive vertical velocity $(w)$ and temperature $(T)$ (Fig. 4a, d, e). In addition, an abrupt change in wind direction also occurred during the fire-front passage at approximately 09:40 EET (Fig. 4g). These observations of weak ambient winds, an upright plume and higher fire intensity are consistent with characteristics associated with plume-dominated fires rather than wind-driven fires (Potter, 2012).

The first plume passage occurred at 09:02-09:11 EET, $T$ and $w$ reached $59^{\circ} \mathrm{C}$ and $5.4 \mathrm{~m} \mathrm{~s}^{-1}$, and the wind direction varied. At this time, the total heat flux, $Q$, remained constant indicating the increase in sensible heat flux was associated with only the passage of the hot plume and not influenced by radiation from the fire front. Increased $Q$ is generally associated with both convective and radiative heating from the fire front. The duration of the second plume passage was shorter (09:23-09:26 EET), followed by temperature increasing to a maximum of $84^{\circ} \mathrm{C}$ and $w$ increasing to $4.1 \mathrm{~m} \mathrm{~s}^{-1}$. At 09:35-09:52 EET, $T$ and $w$ reached maximum values of $148^{\circ} \mathrm{C}$ and $9.0 \mathrm{~m} \mathrm{~s}^{-1}$, respectively, total heat flux, $Q$, was $20-40 \mathrm{~kW} \mathrm{~m}^{-2}$, and the $\mathrm{CO}_{2}$ plume concentrations were in the range of 2000-3000 ppm (Fig. 4a). This period is when the fire front passed under the instruments as indicated by the sharp increase in $Q$ (Fig. 4b). After 10:02 EET, the area around the mast was burning more steadily but with a decreasing intensity. At 10:03 EET, $T$ and $w$ maxima were $41^{\circ} \mathrm{C}$ and $4.2 \mathrm{~m} \mathrm{~s}^{-1}$, respectively, and, at 10:36EET, $T$ and $w$ maxima were $26^{\circ} \mathrm{C}$ and $2.5 \mathrm{~m} \mathrm{~s}^{-1}$, respectively. When the $w$ data were classified according to $T$, the average $w=4.5 \pm 2.0$ for $T>80^{\circ} \mathrm{C}$.

Both the sensible heat flux and TKE were calculated using $10 \mathrm{~Hz}$ data from the sonic anemometer. Perturbations in $u$ and $T$ (sonic temperature) were calculated from the $30 \mathrm{~min}$ mean and the sensible heat flux and TKE were averaged to $1 \mathrm{~min}$ in order to isolate fluxes associated with the firefront passage. During the fire-front passage, the sensible heat 

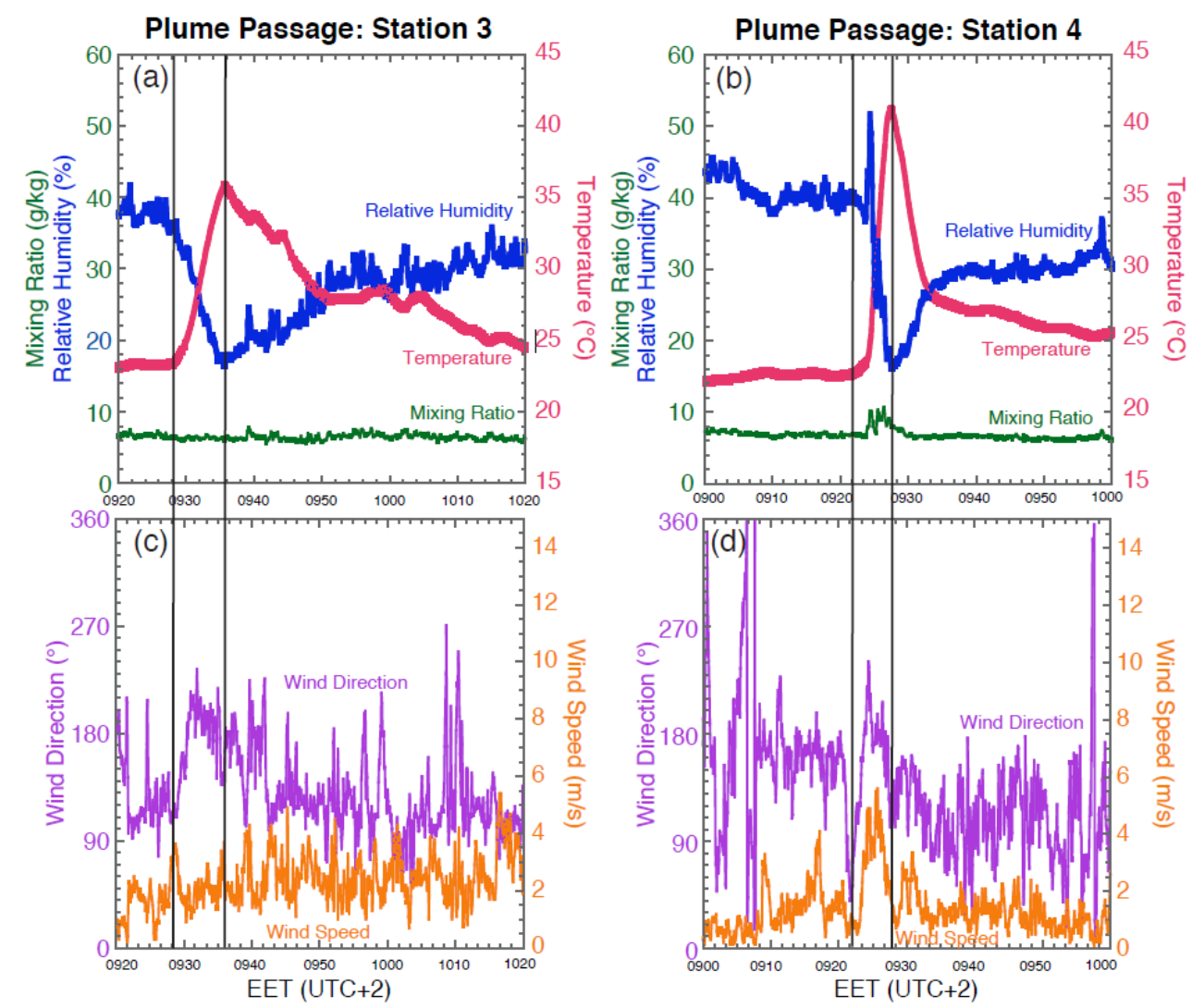

Fig. 5. Observations at the top of two meteorological stations outside of the perimeter of the burning area.

flux $\left(H_{\mathrm{s}}\right)$ increased to $20 \mathrm{~kW} \mathrm{~m}^{-2}$ and peaked to $58 \mathrm{~kW} \mathrm{~m}^{-2}$ (Fig. 4b). Sharp increases in $H_{\mathrm{s}}$ indicate when the plume impinges on the mast and instrumentation, and sharp decreases in sensible heat flux indicate when the plume has passed. The turbulent kinetic energy increased from approximately $1 \mathrm{~m}^{2} \mathrm{~s}^{-2}$ before the plume and fire-front passage to nearly $15 \mathrm{~m}^{2} \mathrm{~s}^{-2}$ during the fire-front passage (Fig. 3c).

In addition to the pole in the middle of the burn area, four surface meteorological stations were deployed around the outside of the burn area (Fig. 1a). Although these surface stations did not experience the fire front directly as they were situated 6-10 m outside the burn area, they sampled the plume and the ambient meteorology surrounding the burn unit. The largest changes in meteorological measurements associated with the plume were collected by stations 3 (southwest of the burn area) and 4 (southeast of the burn area). These two stations recorded the more intense passage of the plume $\left(13^{\circ} \mathrm{C}\right.$ and $18^{\circ} \mathrm{C}$ rises in temperature associated with the plume passage, respectively; Fig. 5a, b) than stations 1 and $2\left(4^{\circ} \mathrm{C}\right.$ and $2{ }^{\circ} \mathrm{C}$ rises; not shown). The fire came closest to station 3 at about 09:10EET and sampled the plume about 09:27-09:50EET (Fig. 4a). The fire came closest to station 4 at about 09:15 EET and sampled the plume about 09:25-09:35 EET (Fig. 5b).
At station 3 around 09:27 EET, the wind shifted from southeasterly to southerly with a weakening wind of 1.5$2 \mathrm{~m} \mathrm{~s}^{-1}$ (Fig. 5c). This shift was coincident with the beginning of a rise in temperature from $23^{\circ} \mathrm{C}$ during which the wind shifted direction from southeasterly to southerly (Fig. 5a, c). By the time of the temperature peak of $35.8^{\circ} \mathrm{C}$ at 09:35 EET, the relative humidity reached its minimum of $16.7 \%$ with a slow rise over about the next $15 \mathrm{~min}$ (Fig. 5a).

In comparison, at station 4 around 09:21-09:24 EET, the wind shifted around to east and northeast, suggesting that this is the inflow to the fire, and decreased (less than $1 \mathrm{~m} \mathrm{~s}^{-1}$, as low as $0.5 \mathrm{~m} \mathrm{~s}^{-1}$ ) (Fig. 5d). A slow rise in temperature to $25^{\circ} \mathrm{C}$ followed (Fig. 5b) when the wind reached its most westerly direction $\left(241^{\circ}\right)$ and increased to as much as $4.9 \mathrm{~m} \mathrm{~s}^{-1}$ (Fig. 5d). Despite the rise in temperature, the relative humidity peaked at $52 \%$ at the time of the most westerly wind (Fig. 5b, d) and the mixing ratio remained elevated at $10 \mathrm{~g} \mathrm{~kg}^{-1}$ which is above the ambient value of $7-8 \mathrm{~g} \mathrm{~kg}^{-1}$. Interestingly, this station was the only one to record such a strong rise in relative humidity, perhaps because the station sampled the plume only about $10 \mathrm{~min}$ after its closest approach to the flames. Enhanced moisture in smoke plumes due to combustion of wildland fuels has been suggested as possibly modifying plume dynamics (Potter, 2005). Direct 
measurements of increased plume moisture have been made previously in grass fuels (Clements et al., 2006; Kiefer et al., 2012) with increases in the water vapor mixing ratio of $1-$ $3 \mathrm{~g} \mathrm{~kg}^{-1}$, and during smoldering fires in the long-leaf pine ecosystems in the southeastern United States (Achtemeier, 2006). From 09:25-09:27 EET, the temperature rose to its peak $\left(41.1^{\circ} \mathrm{C}\right)$, and the relative humidity decreased from 25 $30 \%$ to $16 \%$ at the peak temperature (Fig. $5 \mathrm{~b}$ ).

\subsection{Trace gases observations}

\subsubsection{Inorganic trace gases}

The trace gases $\mathrm{O}_{3}, \mathrm{NO}_{\mathrm{x}}, \mathrm{SO}_{2}, \mathrm{CO}$ and $\mathrm{CO}_{2}$, which are routinely measured at six different altitudes in the mast, should all have clearly elevated concentrations in a biomass-burning plume (e.g., Radke et al., 1991). However, in the data from the mast, the concentrations of most of them deviated very little from the background concentrations during the whole experiment (Fig. 3). The time series of trace gas concentrations measured from the mast shows that the smoke plume arriving at the mast was narrow and patchy. The clearest concentration variations were for $\mathrm{CO}$ (Fig. 3e). During the flaming phase, the highest $\mathrm{CO}$ concentration of $236 \mathrm{ppb}$ was measured at 09:14 EET at an altitude of $33.6 \mathrm{~m}$. This concentration was $127 \mathrm{ppb}$ above the then background value of $109 \mathrm{ppb}$. CO reached the peak value of $372 \mathrm{ppb}$, with the excess concentration $\Delta \mathrm{CO}=263 \mathrm{ppb}$ during the smoldering phase at 12:40EET. The last two clear CO peaks were observed at 13:37 EET when $\triangle \mathrm{CO}$ was $246 \mathrm{ppb}$ and at 14:37 EET when $\triangle \mathrm{CO}$ was $136 \mathrm{ppb}$.

The variations of $\mathrm{CO}_{2}$ concentrations were very small (Fig. 3f), suggesting that the variation was mainly due to both photosynthesis and boundary-layer growth during the day. There was only one $1 \mathrm{~min}$ data point when $\mathrm{CO}_{2}$ concentration was clearly above the baseline. This result would not change even if the baseline were calculated for each altitude separately. The excess concentrations of $\mathrm{CO}_{2}$ and $\mathrm{CO}$ are generally used for calculating the modified combustion efficiency $\mathrm{MCE}=\Delta \mathrm{CO}_{2} /\left(\Delta \mathrm{CO}_{2}+\Delta \mathrm{CO}\right)$, which indicates whether the combustion is flaming or smoldering. It provides a measure of the relative mix of flaming and smoldering combustion with the MCE approaching 1 for pure flaming combustion (e.g., Ward and Hao, 1992; Yokelson et al., 1996; Hobbs et al., 2003; van Leeuwen and van der Werf, 2011). However, the $\mathrm{CO}_{2}$ data are not good for calculating the MCE. The CO monitor detected several peaks that can be associated with the smoke but the $\mathrm{CO}_{2}$ monitor did not detect more than the one peak. This suggests that even though the $40 \mathrm{ppb}$ precision of the $\mathrm{CO}_{2}$ monitor was adequate the temporal coverage of the $\mathrm{CO}_{2}$ measurements was not sufficient.

$\mathrm{NO}_{\mathrm{x}}$ and $\mathrm{SO}_{2}$, on the other hand, did have some peak concentrations above their baselines that were related to peaks in $\triangle \mathrm{CO}$ during the flaming phase (Fig. 6). The $\mathrm{NO}_{\mathrm{x}}$ concentrations had peaks also at times when no other indications

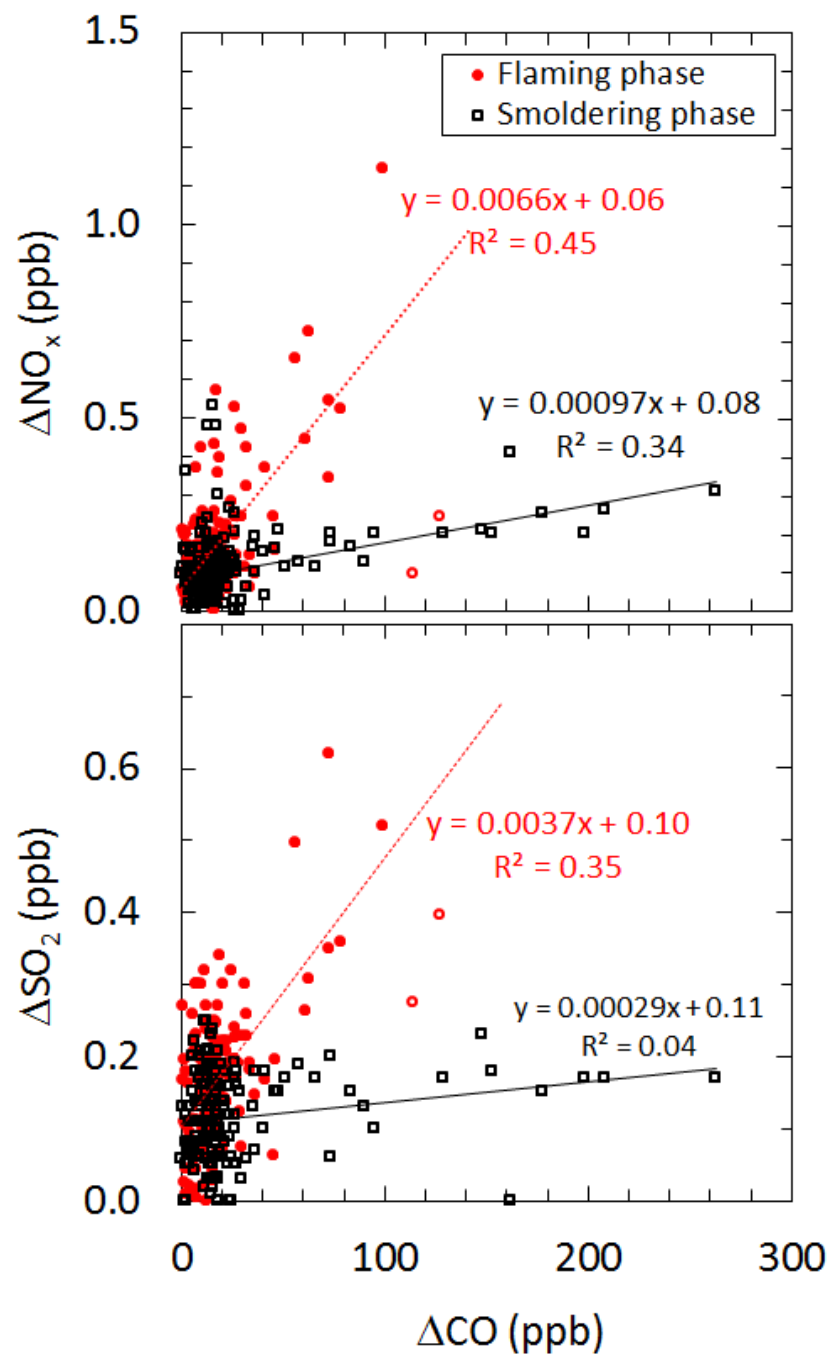

Fig. 6. Excess $\mathrm{NO}_{\mathrm{x}}$ and excess $\mathrm{SO}_{2}$ concentrations as a function of excess $\mathrm{CO}$ concentration at the SMEAR II mast during the flaming and smoldering phases.

of the smoke plume were present - for instance, the three highest peaks during the smoldering phase. A probable explanation for these peaks is car traffic occurring around the station during the burning.

\subsubsection{Organic trace gases}

The time series of selected VOCs measured with PTR-MS at the two locations described in Sect. 2.3.1 are plotted together with the CO data from the mast in Fig. 7. The PTRMS unit that operated in the REA cottage and took its sample from above the canopy, at $16 \mathrm{~m}$ above ground, sampled some of the clearest smoke plume passages during the flaming phase, but no data were available after 12:00 EET, so here only the flaming-phase data are discussed. The unit at the SMEAR II main building that took its sample air from $10 \mathrm{~m}$ above ground level did not detect most of the plumes. This 
Table 3. Emission ratios of VOCs $(\Delta \mathrm{X})$ and their standard errors (s.e.) obtained from a linear regression of $\Delta \mathrm{X}$ vs. the excess carbon monoxide concentration $\Delta \mathrm{CO}$. The data are sorted according to the squared correlation coefficient $r^{2}$. For comparison, the respective ratios are calculated from the emission factors of Akagi et al. (2011) and Simpson et al. (2011). $R \pm d R$ : the ratio of the emission ratio in the present study to that presented by Akagi et al. (2011) and Simpson et al. (2011).

\begin{tabular}{|c|c|c|c|c|c|c|}
\hline \multirow{3}{*}{$\begin{array}{l}\text { Compound }(m / z) \\
\text { methacrolein, methyl vinyl ketone }(71)\end{array}$} & \multicolumn{2}{|l|}{ This study } & \multicolumn{2}{|c|}{ Akagi et al. (2011) } & \multicolumn{2}{|c|}{ Simpson et al. (2011) } \\
\hline & $E R_{\mathrm{X} / \mathrm{CO}} \pm d E R$ & $r^{2}$ & $E R_{\mathrm{X} / \mathrm{CO}} \pm d E R$ & $R \pm d R$ & $E R_{\mathrm{X} / \mathrm{CO}} \pm d E R$ & $R \pm d R$ \\
\hline & $(5.6 \pm 0.4) \times 10^{-3}$ & 0.880 & $(9.0 \pm 3.2) \times 10^{-4(1)}$ & $6.2 \pm 2.2$ & $(4.9 \pm 0.3) \times 10^{-4}$ & $11 \pm 1$ \\
\hline isoprene, methylbutenol fragment, furan (69) & $(5.9 \pm 0.4) \times 10^{-3}$ & 0.874 & $(3.1 \pm 2.0) \times 10^{-3(2)}$ & $1.9 \pm 1.2$ & $(1.3 \pm 0.2) \times 10^{-3(2)}$ & $4.6 \pm 0.6$ \\
\hline methyl ethyl ketone (73) & $(1.1 \pm 0.1) \times 10^{-2}$ & 0.807 & $(6.7 \pm 2.4) \times 10^{-4}$ & $17 \pm 6$ & $(3.8 \pm 1.0) \times 10^{-4}$ & $30 \pm 8$ \\
\hline butanol, hydroxyacetone (75) & $(1.4 \pm 0.2) \times 10^{-2}$ & 0.750 & & & & \\
\hline formaldehyde (31) & $(8.9 \pm 1.3) \times 10^{-3}$ & 0.674 & $(1.4 \pm 0.1) \times 10^{-2}$ & $0.6 \pm 0.5$ & $(1.8 \pm 0.3) \times 10^{-2}$ & $0.5 \pm 0.1$ \\
\hline methyl salicylate (153) & $(2.2 \pm 0.3) \times 10^{-3}$ & 0.652 & & & & \\
\hline acetic acid $(61)$ & $(3.2 \pm 0.5) \times 10^{-2}$ & 0.650 & $(1.6 \pm 1.1) \times 10^{-2}$ & $2.0 \pm 1.4$ & & \\
\hline hexenal (99) & $(8.6 \pm 1.6) \times 10^{-3}$ & 0.636 & & & & \\
\hline cis-3-hexenol, hexanal (101) & $(1.2 \pm 0.2) \times 10^{-2}$ & 0.629 & & & & \\
\hline methylbutenol (87) & $(1.0 \pm 0.2) \times 10^{-2}$ & 0.627 & & & & \\
\hline cis-3-hexenol fragment, hexanal fragment, methylfuran (83) & $(9.8 \pm 1.8) \times 10^{-3}$ & 0.617 & & & & \\
\hline C9-aromatics (121) & $(1.9 \pm 0.3) \times 10^{-3}$ & 0.617 & & & & \\
\hline dimethylfuran (97) & $(1.4 \pm 0.4) \times 10^{-2}$ & 0.616 & $(1.3 \pm 0.5) \times 10^{-4}$ & $102 \pm 41$ & & \\
\hline toluene (93) & $(3.3 \pm 0.6) \times 10^{-3}$ & 0.605 & $(1.2 \pm 0.4) \times 10^{-3}$ & $2.8 \pm 1.1$ & $(6.7 \pm 1.6) \times 10^{-4}$ & $4.9 \pm 1.5$ \\
\hline hexanol (103) & $(4.0 \pm 0.8) \times 10^{-3}$ & 0.589 & & & & \\
\hline methanol (33) & $(5.8 \pm 1.2) \times 10^{-2}$ & 0.587 & $(1.9 \pm 1.3) \times 10^{-2}$ & $3.0 \pm 2.1$ & $(9.6 \pm 1.9) \times 10^{-3}$ & $6.1 \pm 1.7$ \\
\hline monoterpene fragments, hexenal fragment (81) & $(1.4 \pm 0.3) \times 10^{-2}$ & 0.579 & & & & \\
\hline 2-vinylfuran, phenol (95) & $(4.2 \pm 0.1) \times 10^{-3}$ & 0.569 & & & & \\
\hline benzene (79) & $(1.0 \pm 0.2) \times 10^{-2}$ & 0.567 & & & & \\
\hline monoterpenes (137) & $(7.2 \pm 1.1) \times 10^{-3}$ & 0.528 & $(5.0 \pm 1.8) \times 10^{-3}$ & $1.4 \pm 0.6$ & $(2.8 \pm 0.2) \times 10^{-3}$ & $2.6 \pm 0.4$ \\
\hline acetonitrile (42) & $(8.6 \pm 2.2) \times 10^{-3}$ & 0.513 & $(3.3 \pm 1.2) \times 10^{-3}$ & $2.6 \pm 1.1$ & $(1.8 \pm 0.3) \times 10^{-2}$ & $4.8 \pm 1.4$ \\
\hline acetaldehyde (45) & $(2.7 \pm 0.7) \times 10^{-2}$ & 0.500 & $(2.5 \pm 1.0) \times 10^{-3}$ & $11 \pm 5$ & & \\
\hline acetone (59) & $(1.1 \pm 0.1) \times 10^{-2}$ & 0.400 & $(2.9 \pm 1.0) \times 10^{-3}$ & $3.7 \pm 1.4$ & $(1.6 \pm 0.4) \times 10^{-3}$ & $6.6 \pm 1.8$ \\
\hline ethanol, formic acid (47) & $(8.5 \pm 1.7) \times 10^{-3}$ & 0.211 & $(3.0 \pm 2.4) \times 10^{-3}$ & $2.8 \pm 2.4$ & & \\
\hline
\end{tabular}

(1) Calculated from the sum of methacrolein and methyl vinyl ketone emission factors in Akagi et al. (2011)

(2) Calculated from the sum of isoprene and furan emission factors in Akagi et al. (2011) and Simpson et al. (2011).

(3) Calculated from the sum of $\alpha$-pinene and $\beta$-pinene emission factors in Akagi et al. (2011) and Simpson et al. (2011).

was probably partly due to the unfavorable wind directions at this station, and partly due to the substantial meandering of the smoke plumes. Below, we only discuss the VOCs measured with the unit in the REA cottage.

Because $\mathrm{CO}$ provided the best evidence of burning among the trace gases measured by the high mast, we compare it to the VOC data, even though they were not measured exactly at the same location. During the flaming phase there were three clear $\mathrm{CO}$ peaks detected in the mast almost simultaneously with the PTR-MS detecting high concentrations of several VOCs. The CO and VOC peaks 1-3 in Fig. 7 were not exactly at the same time, but they were considered here to be close enough to associate them with each other. In addition, even the shape of peak 1 over 9 min is very similar for $\mathrm{CO}$ and several of the VOCs. Therefore, these data points, together with peaks 2 and 3 were used for calculating linear regressions of $\Delta \mathrm{X}$ vs. $\Delta \mathrm{CO}$, where $\Delta \mathrm{X}$ is the concentration of VOC $\mathrm{X}$ over the baseline, as explained in Sect. 2.4. The scatterplots with the linear regressions for the 12 compounds with the highest correlation coefficients are shown in Fig. 8. The regressions were calculated by forcing the offset to zero, and the slope can be considered to be the emission ratio $E R_{\mathrm{X} / \mathrm{CO}}$ (cf. Sect. 2.4). The results are presented in Table 3, where the uncertainties of the slopes are also shown. The uncertainties are the standard errors of the slopes obtained from the linear regressions. The highest correlation coefficients with
CO were obtained for $m / z$ associated with methacrolein and isoprene.

The emission ratios cannot be used as emission factors of emitted VOC per mass of burned biomass, but they can be compared to other published data. Akagi et al. (2011) presented the emission factors of several trace gases and aerosols of burned dry biomass in various types of forests, including boreal forests. For $\mathrm{CO}$ from boreal forest burns, they presented the emission factor of $127 \pm 45 \mathrm{~g} \mathrm{~kg}^{-1}$. For formaldehyde, the emission factor was $1.86 \pm 1.26 \mathrm{~g} \mathrm{~kg}^{-1}$. To compare these values with those calculated from our data, the molar ratios have to be calculated. The molar mass of $\mathrm{CO}$ is $28 \mathrm{~g} \mathrm{~mol}^{-1}$ and that of formaldehyde (HCHO) is $30 \mathrm{~g} \mathrm{~mol}^{-1}$. So the molar ratio of the emission factors of formaldehyde to $\mathrm{CO}$ is $\left(1.86 \mathrm{~g} / 30 \mathrm{~g} \mathrm{~mol}^{-1}\right) /\left(127 \mathrm{~g} / 28 \mathrm{~g} \mathrm{~mol}^{-1}\right) \approx 0.014$. The uncertainty of a ratio $R=a / b$ can be calculated from $\delta R=$ $R \sqrt{(\delta a / a)^{2}+(\delta b / b)^{2}}$. This formula was used with the uncertainties of the emission factors in the table of Akagi et al. (2011) to calculate the uncertainties of the emission ratios. To compare these ratios with those obtained from the present study, it has to be taken into account that the PTRMS measures compounds that have a certain mass-to-charge ratio $(m / z)$. For instance, $m / z=71$ measures methacrolein and methyl vinyl ketone. In comparing them to the present 


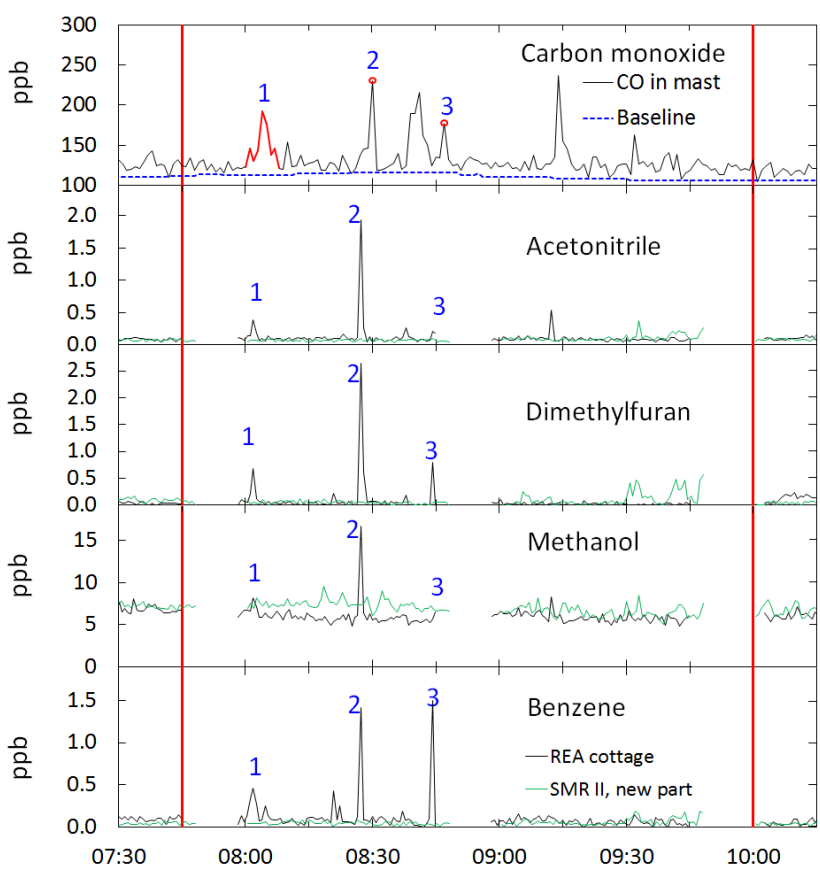

Fig. 7. Data of selected VOCs measured with PTR-MS at two locations and carbon monoxide measured by the mast at all altitudes. The numbers on the peaks and the red line for $\mathrm{CO}$ in peak 1 denote the data that were used for the regressions in Fig. 8 and Table 3.

study, the emission factors of methacrolein and methyl vinyl ketone presented by Akagi et al. (2011) were first added and then the above molar conversion was calculated. Another example is monoterpenes, $m / z=000137$. Akagi et al. (2011) present the emission factors of $\alpha$-pinene and $\beta$-pinene. The sum of these was calculated. The respective emission ratios are presented in Table 3. To further compare these ratios with those calculated from our measurements, the ratio of the emission ratios $\left(E R_{\mathrm{X} / \mathrm{CO}}\right.$ (this study $\left.)\right) /\left(E R_{\mathrm{X} / \mathrm{CO}}\right.$; Akagi et al., 2011) and the respective uncertainties were also calculated. Simpson et al. (2011) presented both emission factors and emission ratios of boreal forest fires. These are also used in Table 3 for comparison. For most of the compounds the emission ratios in the present study are larger than those presented both by Akagi et al. (2011) and Simpson et al. (2011) (Table 3). Formaldehyde has the only emission ratio that is smaller, and for monoterpenes it is relatively close to that of Akagi et al. (2011). The largest differences are for dimethylfuran and for methyl ethyl ketone.

\subsection{Aerosol at SMEAR II}

\subsubsection{Size distributions}

The time series of aerosol number concentrations, the air ion and aerosol number size distributions, and the concentrations of organics show that even though the wind blew from the right direction only for a short time, some distinct smoke peaks could be observed at the aerosol cottage and at the SMEAR II main building where the AMS was operated (Fig. 9). Although the AMS measures the concentrations of organics, sulfate, nitrate, chloride, and ammonium, only the concentrations of organics increased in the plume. The concentration of BC measured with the aethalometer increased above its baseline values only during the flaming phase (Fig. 9f). The peak 5 min average BC concentration of $3.4 \mu \mathrm{g} \mathrm{m}^{-3}$ was measured at 08:07 EET. In the AODTWR above the canopy level, the peak $1 \mathrm{~min}$ BC concentration of $5.4 \mathrm{\mu g} \mathrm{m}^{-3}$ was measured with the MAAP at 08:02 EET. In the plumes passing by the aerosol cottage during the smoldering phase, the $\mathrm{BC}$ concentrations did not increase at all; in the AODTWR, two 1 min peaks were detected (Fig. 9f).

The time series also shows one of the problems of the analysis. For instance, the sum of all species observed with the AMS is clearly lower than the mass concentration calculated from the number size distributions in the size range $D_{\mathrm{p}}<600 \mathrm{~nm}$ using a density of $1.5 \mathrm{~g} \mathrm{~cm}^{-3}$. In addition, some of the peak concentrations observed with the other aerosol instruments were not observed with the AMS at all (Fig. 9). The main reason is that the AMS and the TDMPS were in different buildings, and the distance between the two sites is about $100 \mathrm{~m}$. In the case of a nearby smoke plume in lowwind-speed conditions, this distance is relevant.

The NAIS data show that cluster-mode $\left(D_{\mathrm{p}}<2 \mathrm{~nm}\right)$ (Fig. 9e) and intermediate-mode $\left(D_{\mathrm{p}}=2-8 \mathrm{~nm}\right)$ (Fig. 9d) air ion number concentrations decreased substantially in the strongest smoke plumes, based on carbon monoxide and particle volume concentrations, both in the flaming and the smoldering phases, suggesting that the ions were attached to the larger aerosols in the plume. The time series also shows that new particle formation occurred during the morning; at 09:20-09:50 EET, the cluster mode concentrations increased and there was a clear nucleation mode also in the size distribution measured with the DMPS. At this time, all indicators of the smoke plume were very low, and wind was for a while blowing from the east at all levels ( $\mathrm{WD}=80^{\circ}-120^{\circ}$ ) so the data suggest that the formation of new aerosol particles was natural and not due to the prescribed fire.

Particle number and volume size distributions were plotted for five selected times (Fig. 10). In the size distributions from the smoke plume, shaded bands are also plotted. This figure presents the range of count median diameters $(\mathrm{CMD})(0.12-0.18 \mu \mathrm{m})$ and volume median diameters (VMD) (0.21-0.3 $\mu \mathrm{m})$ of smoke aerosol accumulation mode from temperate-forest prescribed fires and wildfires in the review by Reid et al. (2005a).

At 07:50 EET, the smoke from the burning area had not yet reached the measurement station, so it represents the baseline size distribution. Three clear modes were apparent, both in the number and volume size distributions. In the number distributions, a nucleation mode occurred at $12 \mathrm{~nm}$, an Aitken mode occurred at $79 \mathrm{~nm}$, and an accumulation mode occurred at $223 \mathrm{~nm}$. In the volume size distributions, an Aitken 

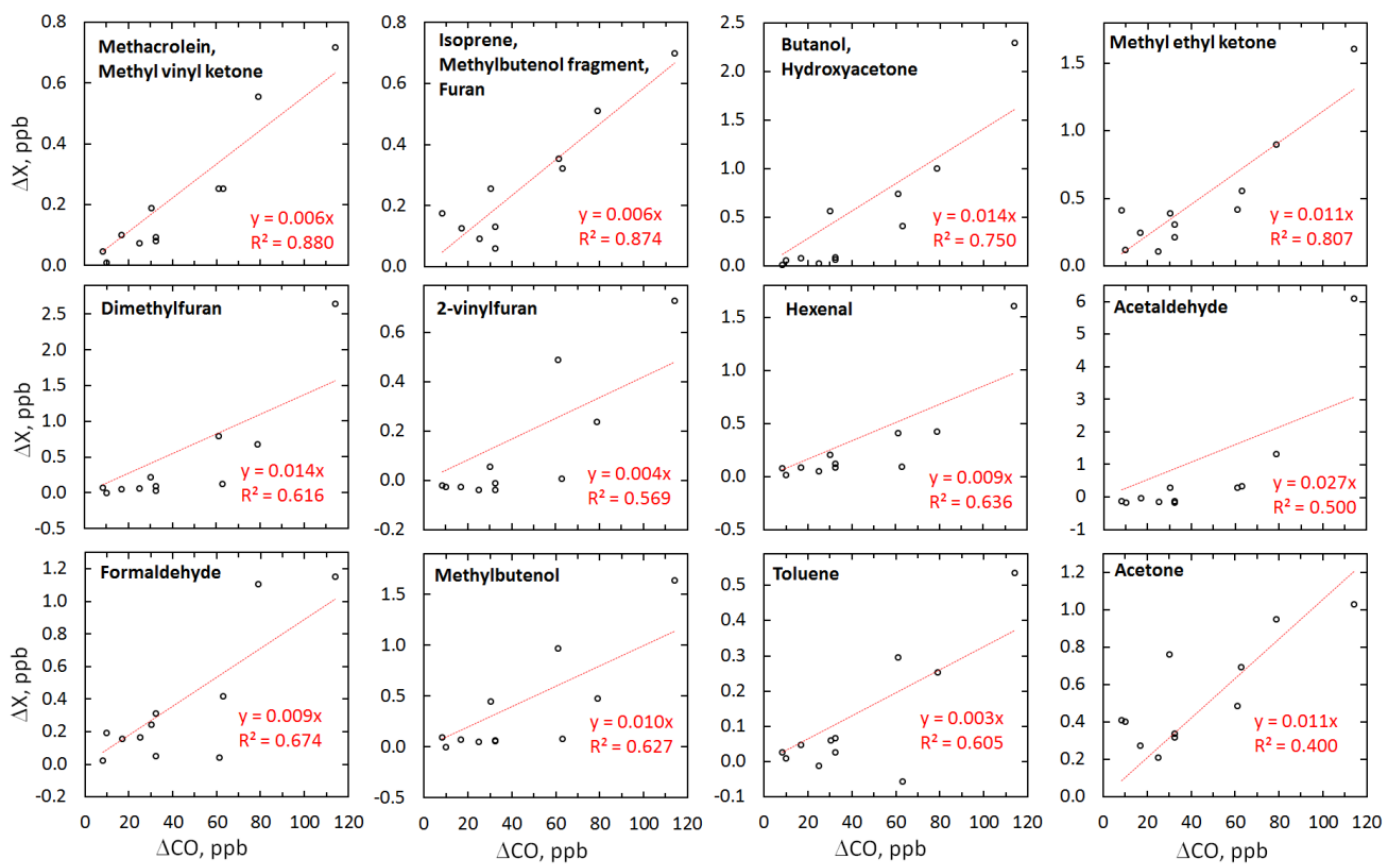

Fig. 8. Relationships of excess concentrations $(\Delta X)$ of organic trace gases to excess carbon monoxide $(\Delta C O)$ concentrations in the smoke plume peaks presented in Fig. 7.

mode occurred at $106 \mathrm{~nm}$, an accumulation mode occurred at $264 \mathrm{~nm}$, and a coarse mode occurred at $3.6 \mu \mathrm{m}$. The integrated mass concentration was $9.4 \mu \mathrm{g} \mathrm{m}^{-3}$ for $D_{\mathrm{p}}<10 \mu \mathrm{m}$.

The size distribution at 08:00EET is the clearest one obtained from the smoke plume during the flaming phase. In the number size distribution, there were four modes, the largest of which was at $D_{\mathrm{g}}=80 \mathrm{~nm}$. The geometric standard deviations (i.e., the widths of the modes) were quite small, ranging from 1.15 to 1.25 , so the fitting was done by assuming that instead of the three largest modes there is only one large mode with $D_{\mathrm{g}}=81 \mathrm{~nm}, \sigma_{\mathrm{g}}=1.58$ (the dashed line at 08:00). In the volume size distribution, there were four modes, the highest concentration of which was at $D_{\mathrm{g}}=153 \mathrm{~nm}$. The integrated mass concentration was $21.6 \mu \mathrm{g} \mathrm{m}^{-3}$, the highest during the flaming phase.

At 09:20EET, there was a very clear nucleation mode at $D_{\mathrm{g}}=8.8 \mathrm{~nm}$, simultaneously with the high positive and negative air ion concentration in the sub- $10 \mathrm{~nm}$ size range (Fig. 9). At this time, the number concentrations in the Aitken and accumulation modes were lower than in the smoke plume size distribution at 08:00EET and not very different from those in the background size distribution at 07:50 EET; the mass concentration of $8.9 \mu \mathrm{g} \mathrm{m}^{-3}$ was actually lower than at 07:50 EET. Therefore, it is reasonable to interpret this size distribution as representing natural new particle formation that is frequently observed at SMEAR II during sunny days (Dal Maso et al., 2005).

The size distribution at 12:40 EET was measured from the thickest smoke plume arriving at the aerosol cottage dur- ing the smoldering phase. It is worth noting that already an hour earlier at 11:41 (Fig. 2h) the visual smoke emissions from the burn were clearly smaller than during the flaming phase (Fig. 2a-f). At 12:40, CO also reached the maximum concentration (Fig. 3e), so the timing of these maxima suggests that this part of the otherwise very patchy plume was wide. In this size distribution, the integrated mass concentration of $28.6 \mu \mathrm{g} \mathrm{m}^{-3}$ was the largest observed in the aerosol cottage during the experiment. In this number size distribution, the largest mode was at $D_{\mathrm{g}}=79 \mathrm{~nm}$, essentially the same size as in the flaming-phase-plume size distribution at 08:00 EET, but the accumulation mode $D_{\mathrm{g}}=244 \mathrm{~nm}$ was larger than that in the flaming phase size distribution. The volume size distribution at 12:40EET was clearly different from that during the flaming phase at 08:00 EET. First, the mode with the largest concentration was at $D_{\mathrm{g}}=318 \mathrm{~nm}$ whereas at 08:00 EET, it was at $D_{\mathrm{g}}=153 \mathrm{~nm}$. Second, in the smoldering-phase-plume volume size distribution, the contribution of the coarse-mode particles was much higher than in the flaming-phase-plume size distribution. Actually, the broad shape of the supermicron size distribution and the high $\sigma_{\mathrm{g}}=2.4$ suggest there were even more modes in the coarse sizes.

At 13:40EET, another smoke plume was observed at the aerosol cottage, again simultaneously with a $\mathrm{CO}$ peak at the mast. This was at a time when little or no visible smoke was observed at the burned site. The number size distribution was narrower with the largest mode at $D_{\mathrm{g}}=122 \mathrm{~nm}$. The volume size distribution also had two clear accumulation modes and 


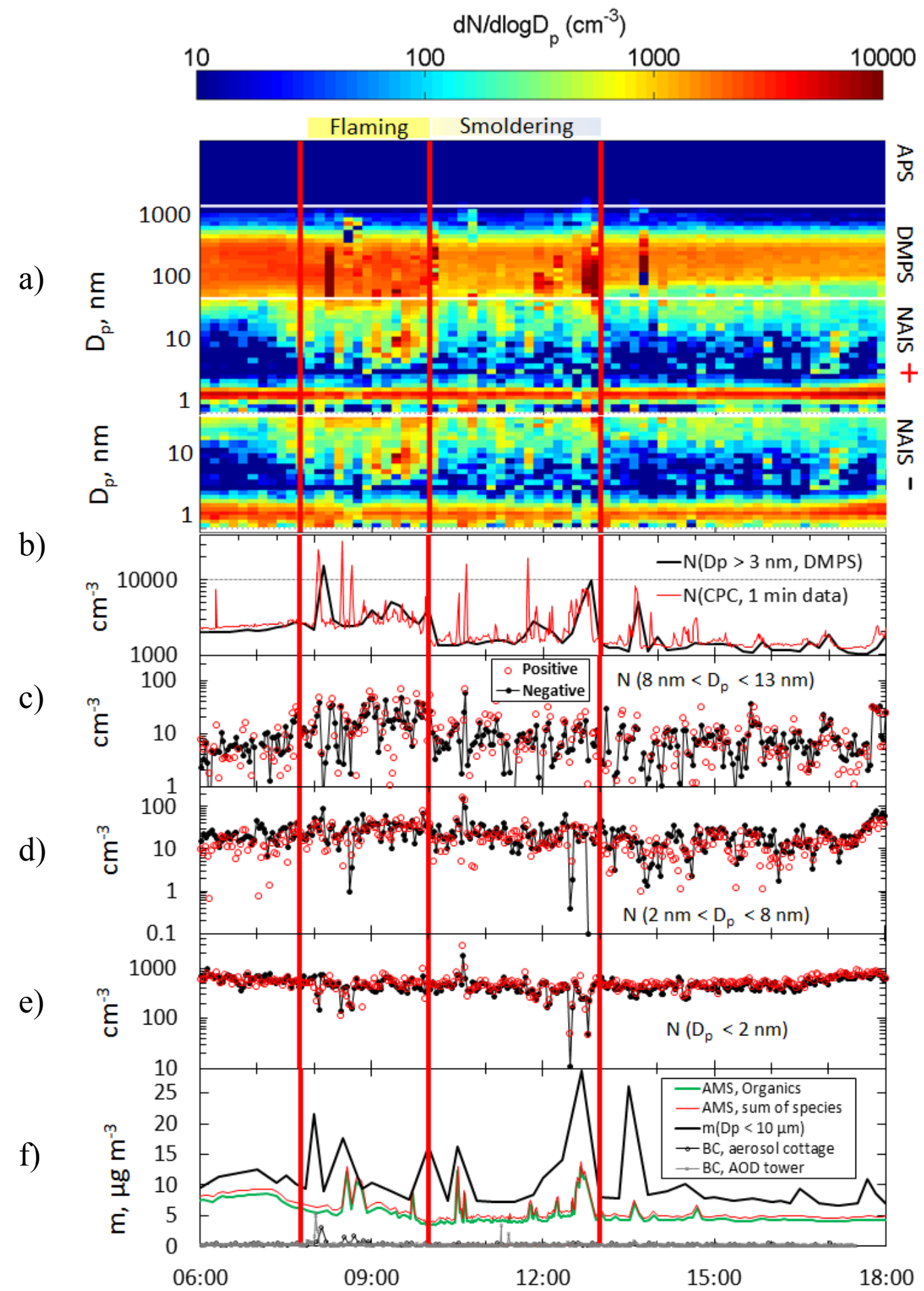

Fig. 9. Data of selected ground-based aerosol measurements at SMEAR II on 26 June 2009. (a) Particle number size distributions measured with the APS and the DMPS, and the positive and negative air ion size distributions measured with the NAIS. (b) Total particle number concentrations measured with a CPC and integrated from the DMPS. (c-e) Air ion number concentrations from the NAIS data in three different size ranges. (f) Concentrations of organics and the sum of all compounds measured with an AMS, mass concentration of concentration of particles smaller than $10 \mu \mathrm{m}$ calculated from the size distributions measured with the DMPS and the APS using the density of $1.5 \mathrm{~g} \mathrm{~cm}^{-3}$, and black carbon concentration at two locations. 

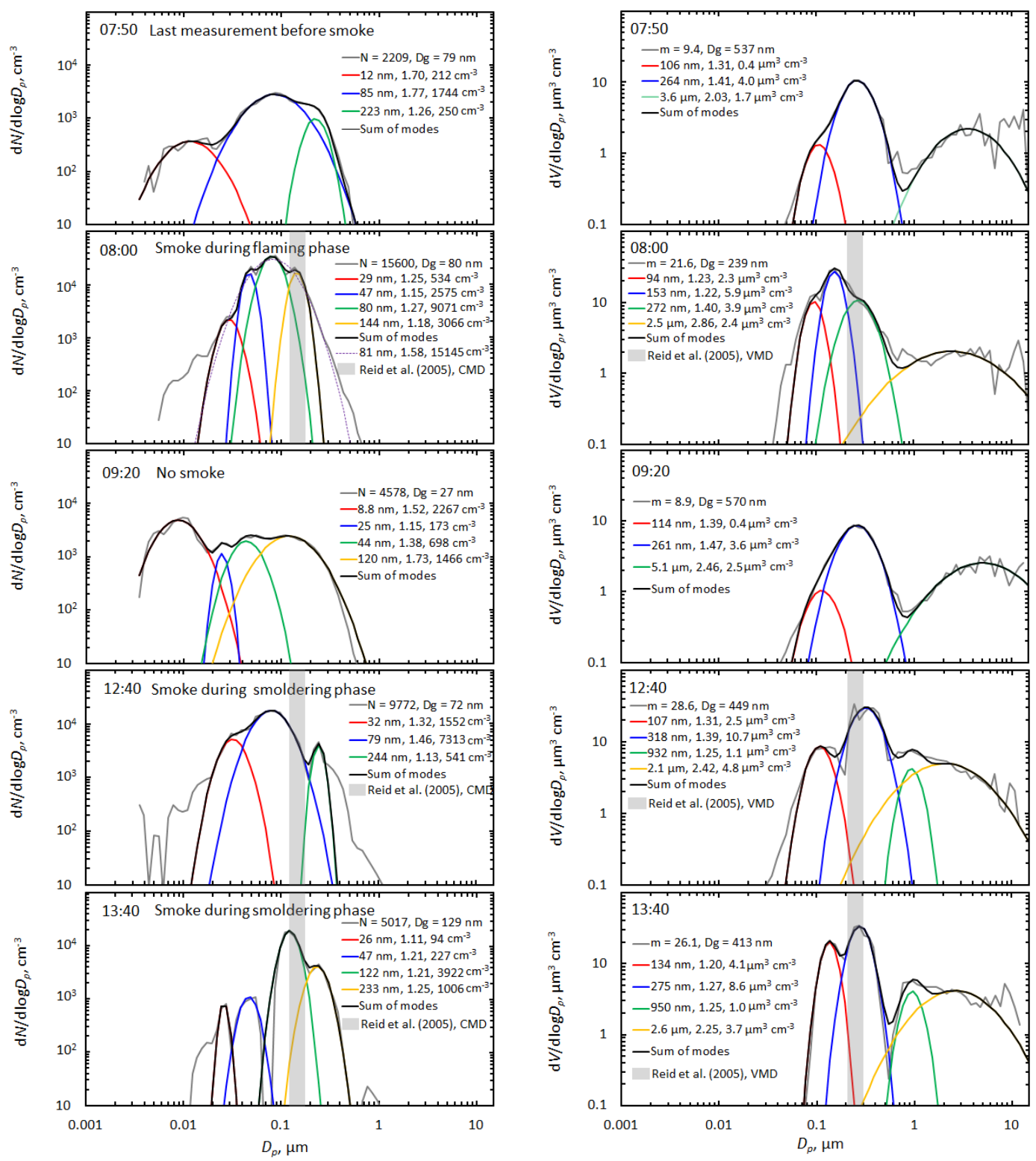

Fig. 10. Selected particle size distributions measured with DMPS and APS in the aerosol cottage. The left column: number size distributions; right column: volume size distributions. In each plot, the grey line represents the measured size distribution and the associated numbers: the number concentration in $\mathrm{cm}^{-3}$ (left column), the mass concentration integrated to $10 \mu \mathrm{m} \mathrm{in} \mu \mathrm{g} \mathrm{m}^{-3}$ calculated assuming a density of $1.5 \mathrm{~g} \mathrm{~cm}^{-3}$ (right column), and the geometric mean diameter $\left(D_{\mathrm{g}}\right)$ of the whole size distribution. The modal parameters are the geometric mean diameter, the geometric standard deviation, and the number or volume concentration of the mode. The grey shaded band in the smoke size distributions shows the range of count median diameters (CMD) and volume median diameters (VMD) of smoke aerosol from temperateforest prescribed fires and wildfires in the review by Reid et al. (2005a).

a broad coarse particle size distribution. The fast passage of the smoke plume creates uncertainty regarding the modal parameters since the smoke plume passages were shorter than the time used for scanning one size distribution. Nevertheless, in both of the size distributions that were measured during the smoldering phase, the mass size distribution had much larger modes than during the flaming phase.
The mode diameters of the size distributions observed during the flaming phase were clearly smaller than those measured by Radke et al. (1991) and those presented in the papers reviewed by Reid et al. (2005a). In the smoldering phase of our experiment, the accumulation mode of the particle size distributions was in the same range as those in Reid et al. (2005a). In contrast to our observations, Hobbs et al. (1996) found that the mode diameter of the size 
a)

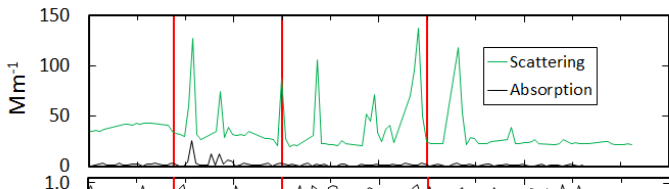

b)

c)

d)

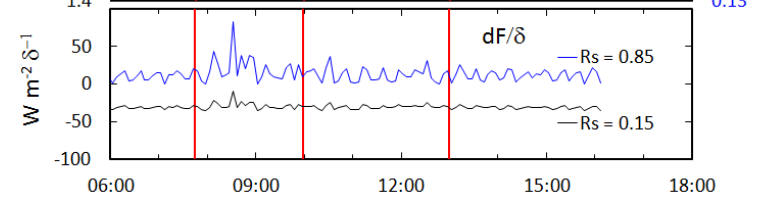

Fig. 11. Optical properties of aerosol observed in the aerosol cottage: (a) scattering and absorption coefficients at $\lambda=550 \mathrm{~nm}$; (b) single-scattering albedo at $\lambda=550 \mathrm{~nm}$; (c) Ångström exponent of scattering over $450 \mathrm{~nm}-700 \mathrm{~nm}\left(\alpha_{\mathrm{sp}}\right)$ and backscatter fraction $b$ at $\lambda=550 \mathrm{~nm} ;(\mathbf{d})$ intrinsic aerosol forcing efficiency for two surface reflectances $\left(R_{\mathrm{S}}\right)$.

distribution was smaller in the plume during the smoldering phase than during the flaming phase.

\subsubsection{Aerosol optical characterization}

In the first smoke plume observed during the flaming phase, the light scattering coefficient $\left(\sigma_{\mathrm{sp}}\right)$ at $\lambda=550 \mathrm{~nm}$ was $127 \mathrm{Mm}^{-1}$ (Fig. 11). Because the mass concentrations obtained from the combined DMPS+APS data are available every $10 \mathrm{~min}$, scattering data, which are available at $5 \mathrm{~min}$ intervals, were averaged over $10 \mathrm{~min}$ for comparison. The peak $\sigma_{\mathrm{sp}}$ in the first smoke plume passage was $93.8 \mathrm{Mm}^{-1}$, whereas the mass concentration in the size range $D_{\mathrm{p}}<10 \mu \mathrm{m}$ was $21.6 \mu \mathrm{g} \mathrm{m}^{-3}$ (Fig. 10, volume size distribution at 08:00EET), which yields a mass scattering efficiency of $4.3 \mathrm{~m}^{2} \mathrm{~g}^{-1}$. The highest $5 \mathrm{~min}$-averaged $\sigma_{\mathrm{sp}}=$ $137 \mathrm{Mm}^{-1}$ was observed in the smoldering phase at the time the mass concentration reached the maximum value of $28.6 \mu \mathrm{g} \mathrm{m}^{-3}$ (Fig. 10). The corresponding $10 \mathrm{~min}$-averaged $\sigma_{\mathrm{sp}}=116.5 \mathrm{Mm}^{-1}$ resulted in a mass scattering efficiency of $4.1 \mathrm{~m}^{2} \mathrm{~g}^{-1}$. These mass scattering efficiencies are somewhat higher than the value of $3.1 \pm 0.9 \mathrm{~m}^{2} \mathrm{~g}^{-1}$ that was obtained from the 3 yr time series at SMEAR II (Virkkula et al., 2011) and than the median value for the whole burning day that was also $3.1 \mathrm{~m}^{2} \mathrm{~g}^{-1}$, but in good agreement with other published values (e.g., Reid et al., 2005b; Malm and Hand, 2007).

Light scattering increased when the smoke plume passed the aerosol cottage, but the absorption coefficient increased only during two short periods in the flaming phase (Fig. 9a),in agreement with laboratory studies showing that

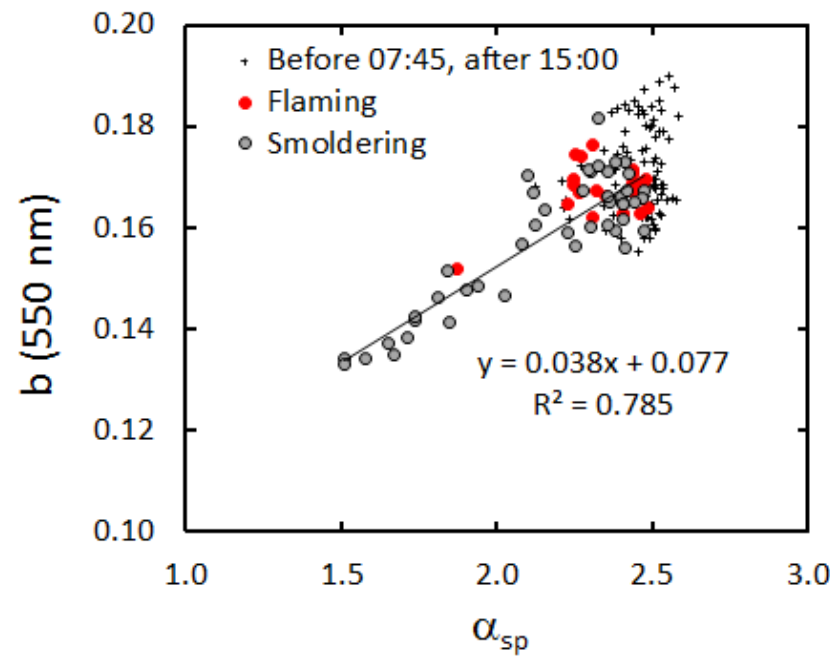

Fig. 12. Backscatter fraction $b$ at $\lambda=550 \mathrm{~nm}$ vs. Ångström exponent of scattering $\left(\alpha_{\mathrm{sp}}\right)$ in the aerosol cottage before the flaming phase and after the last plume was observed (crosses), during the flaming phase (red circles), and during the smoldering phase (grey circles). The regression line was fitted with the smoldering-phase data.

$\mathrm{BC}$ is produced in flaming combustion but less in smoldering combustion (e.g., McMeeking et al., 2009). The aerosol was not very dark: the single-scattering albedo $\omega_{0}$ is about $0.2 \pm 0.1$ for pure BC, but during the experiment the lowest $\omega_{0}$ was about 0.7 and in the strongest plume during the flaming phase 0.82 . These values are in line with the average $\omega_{0}=0.83 \pm 0.11$ of the fires studied by Radke et al. (1991). During the smoldering phase, $\omega_{0}$ was $\approx 0.9$ and did not deviate from the background values during the smoke plumes (Fig. 9b). That $\omega_{0}$ was larger during the smoldering phase is also in agreement with earlier studies (e.g., Hobbs et al., 1996; Reid et al., 2005b).

In general, the backscatter fraction $b$ of larger particles is smaller than that of smaller particles, so the size relationship of the backscatter fraction $b$ is qualitatively similar to that of the Ångström exponent of scattering, $\alpha_{\text {sp. }}$. This relationship was also observed in the smoke plumes. There were clear differences in $\alpha_{\mathrm{sp}}$ and $b$ between the flaming and smoldering phases; both parameters were clearly lower in the smoke plumes observed during the latter phase (Fig. 8). In the plumes during the flaming phase, the average $\alpha_{\mathrm{sp}}$ and $b$ were $2.25 \pm 0.01$ and $0.171 \pm 0.001$, respectively, and in the smoldering phase $1.56 \pm 0.07$ and $0.134 \pm 0.001$, respectively. These observations and the higher contribution of coarse-mode particles in the smoldering phase (Fig. 7) than in the flaming phase are in line with the general picture of the size relationships of both $\alpha_{\mathrm{sp}}$ and $b$. The two parameters were especially well correlated during the smoldering phase (Fig. 9). 


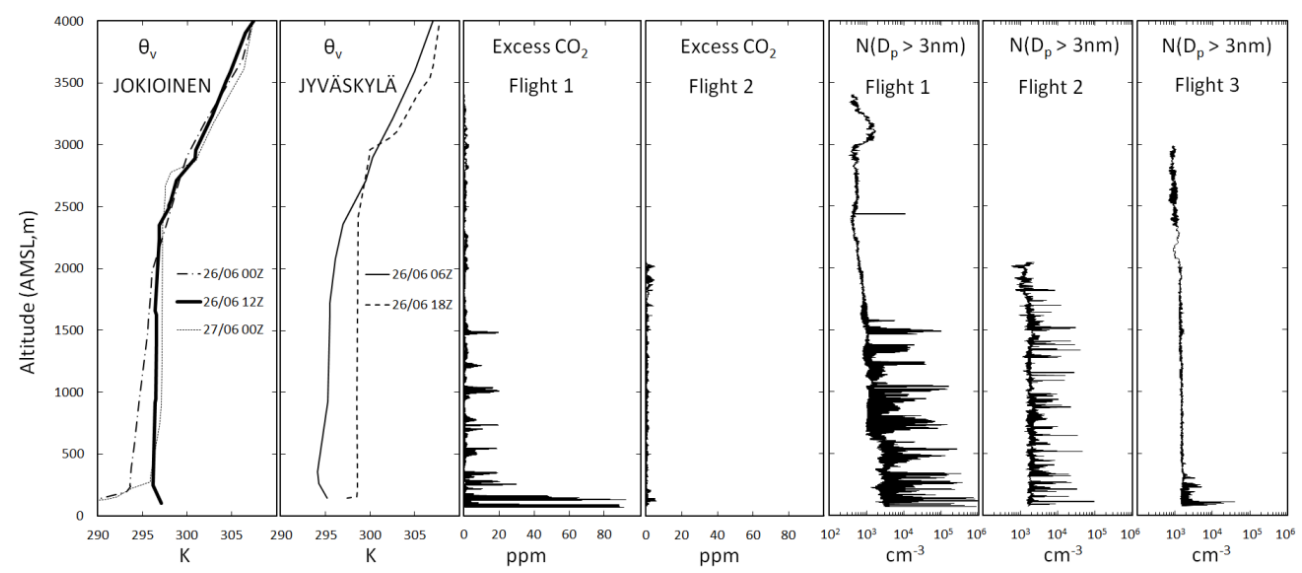

Fig. 13. Vertical profiles of virtual potential temperature $\left(\theta_{\mathrm{V}}\right)$, excess $\mathrm{CO}_{2}$ and total particle number concentrations during the experiment day. For flight 3 , no excess $\mathrm{CO}_{2}$ data are shown because they did not deviate from zero. The $\theta_{\mathrm{v}}$ data are from meteorological soundings from two sites, the Jokioinen Observatory and the Tikkakoski Airport in Jyväskylä.

The single-scattering albedo and the backscatter fraction were used for estimating the radiative forcing efficiency $\Delta F / \delta$ from Eq. (7). $\Delta F / \delta$ is negative for dark surfaces $\left(R_{\mathrm{S}}=\right.$ $0.15)$, both during the flaming and smoldering phases, even for the darkest aerosol during the flaming phase (Fig. 8d). For $R_{\mathrm{S}}$, the value of 0.85 was used to assess the effect of the aerosols above snow surfaces. There, the observed aerosol would have a positive radiative forcing (Fig. 8d). The flaming-phase aerosol would heat the atmosphere much more strongly than the smoldering phase aerosol.

To estimate the direct radiative forcing, $\Delta \mathrm{F} / \delta$ should be multiplied by the aerosol optical depth $\delta$. However, we do not have any measurement data on the smoke plume optical depth. The sunphotometer that was in the tower east of the aerosol cottage did not detect the smoke at all even though the MAAP that was at the same location did. The main reason is that most of the smoke plume did not flow between the sunphotometer and the Sun. Another reason is that the sunphotometer made one instantaneous measurement every $15 \mathrm{~min}$ according to AERONET (AErosol RObotic NETwork) settings and the smoke plume passed by the mast only during short 1-2 min periods (Fig. 6).

Satellite data were also studied for possible signs of the fire plume. The Moderate Resolution Imaging Spectroradiometer (MODIS) onboard the Terra and Aqua platforms made two overpasses of the site shortly after the fire at 11:40 EET (Terra) and 11:55 EET (Aqua). The $250 \mathrm{~m}$ resolution visible wavelength (MODIS bands 1 and 2) and $1 \mathrm{~km}$ resolution thermal infrared channels data were inspected, but no signs of the fire plume were observed. The $10 \times 10 \mathrm{~km}$ MODIS Aerosol Optical Depth (AOD) product is not elevated near the site (AOD < 0.05). The Multi-angle Imaging SpectroRadiometer (MISR) $275 \mathrm{~m}$ resolution data were also checked for the same Terra overpass, with no sign of the plume. The satellite overpasses missed the strongest flaming phase, and the resolution is not high enough to catch the remaining plume.

\subsection{Observations on mobile platforms}

There were three different types of mobile measurements: the research aircraft, Sniffer and the portable particle counters. Here we discuss observations that were aimed at studying the horizontal and vertical dispersion of particles.

Three research flights were conducted during the day. The plan was to fly through the smoke plume at several altitudes up to about $3000 \mathrm{~m}$ above ground level. The first flight was flown during the flaming phase, the second flight was flown during the clear smoldering phase, and the last flight was flown when no smoke was observed on the ground.

During flight 1 (07:40-10:15 EET), elevated particle number and $\mathrm{CO}_{2}$ concentrations indicated the smoke plume up to an altitude of about $1500 \mathrm{~m}$ a.m.s.l. (Fig. 13). This altitude was $200 \mathrm{~m}$ lower than the stable layer (i.e., where the virtual potential temperature $\theta_{v}$ increased dramatically with height) in the routine meteorological sounding at the Tikkakoski Airport in Jyväskylä, about $90 \mathrm{~km}$ northeast from Hyytiälä, at 08:00 EET at the beginning of the flaming phase. Therefore, the smoke rose up to about the top of the boundary layer, but not above it. We flew through the smoke plume at several altitudes and analyzed the 25 most obvious plume crossings and determined the plume width from the particle number concentration data. With a flight speed of $38 \pm 2 \mathrm{~m} \mathrm{~s}^{-1}$, at about $100 \mathrm{~m}$ above ground level, the plume was crossed in about 3$4 \mathrm{~s}$, yielding a plume width of about $120 \mathrm{~m}$. At $1200 \mathrm{~m}$ above ground level, the plume width was $800 \pm 100 \mathrm{~m}$. This analysis is found in the companion paper by Virkkula et al. (2013). 


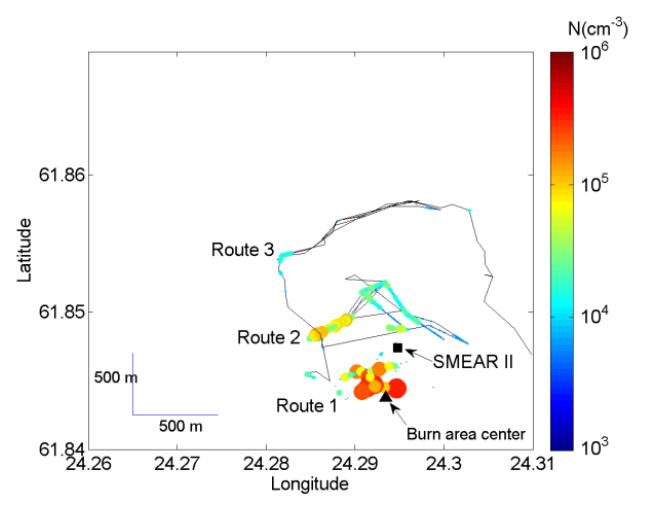

a)

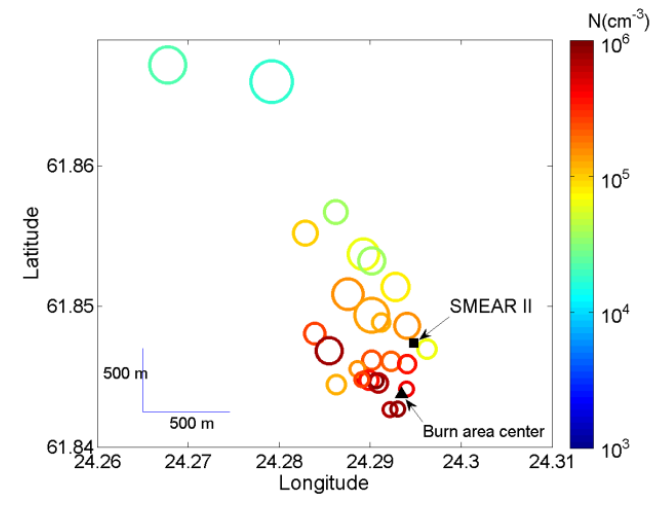

b)

Fig. 14. Horizontal spread of the smoke plume (a) at ground level as observed with the portable CPCs and (b) as observed in the aircraft during flight 1. In (a) both the diameter and the symbol color are scaled according to the concentration. In (b) the color scale is for the concentration and the circle size is scaled according to the diameter of the plume. The concentrations in (a) are all concentrations larger than $10^{4} \mathrm{~cm}^{-3}$ and in (b) the maximum concentrations in the plume crossings.

During flight 2 (11:05-13:40EET), the boundary layer depth had increased to about $2300 \mathrm{~m}$ a.m.s.l. according to the sounding at the Jokioinen Observatory at 14:00 EET (Fig. 13). We observed elevated number concentrations at $2000 \mathrm{~m}$ a.m.s.l., but $\mathrm{CO}_{2}$ concentrations did not exceed background concentrations at any level. During flight 3 (15:5017:55 EET), particle number concentrations exceeded background concentrations up to about $1000 \mathrm{~m}$ a.m.s.l., but $\mathrm{CO}_{2}$ concentration did not rise above the background concentration.

The horizontal dispersion of the smoke plume is visualized by plotting the concentrations measured with the portable CPCs on the ground and with the CPC in the aircraft as a function of the latitude and longitude. For the groundlevel measurements, Fig. 14a shows the paths the pedestrians walked and the concentrations at those locations where the concentration was larger than 10000 particles $\mathrm{cm}^{-3}$. For the airborne measurements, Fig. 13b shows the locations, the maximum concentrations and the widths of the plumes in the 27 plume passages mentioned above. Both at ground level and aloft, the plume was transported in the direction of the average wind direction at $73 \mathrm{~m}$ in elevation measured at the SMEAR II mast.

The location and concentration data from ground-based and airborne measurements were used to estimate the decrease of the concentrations as a function of the distance from the center of the burn area (Fig. 15). The three-dimensional distance was calculated from the center of the burn area to the point location of the measurement. The pedestrian data were arranged in $100 \mathrm{~m}$ distance bins, and the maximum of each of these was used for the calculations. The three data points from Sniffer are the average concentrations over 3-5 min at distances of $120 \mathrm{~m}, 180 \mathrm{~m}$ and $250 \mathrm{~m}$ downwind and $250 \mathrm{~m}$ downwind from the edge of the burned area. For the airborne data, the maxima of each plume crossing were used.

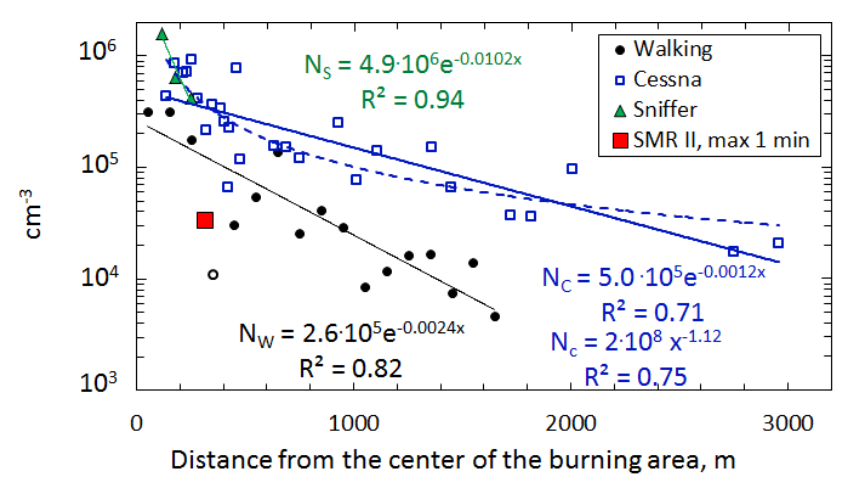

Fig. 15. Particle number concentration as a function of 3dimensional distance from the center of the burning area measured in the Cessna, with the portable CPCs on the ground (walking, $N_{\mathrm{W}}$ ), in the aeroplane (Cessna, $N_{\mathrm{C}}$ ), and on the ground in the van (Snif$\mathrm{fer}, N_{\mathrm{S}}$ ). The walking data points are the maximum concentrations of each $100 \mathrm{~m}$ distance bin, the aircraft data points are the maxima in each plume crossing and the Sniffer data points the 3-5 min average concentrations measured at three standing locations of the van. The SMEAR II data point denotes the maximum $1 \mathrm{~min}$ particle number concentration in the aerosol cottage during the experiment. The solid lines denote fittings of the exponential function $N_{0} \mathrm{e}^{-k x}$ and the dashed line the fitting of a power law $N_{0} \mathrm{x}^{-b}$, where $x$ is the distance from the center of the burn area.

The highest particle number concentration, $1.6 \times 10^{6} \mathrm{~cm}^{-3}$, was measured with the ELPI in Sniffer at $120 \mathrm{~m}$ from the burn area. The highest particle number concentration from the research aircraft, $0.94 \times 10^{6} \mathrm{~cm}^{-3}$, was measured at a height of $118 \mathrm{~m}$ above ground. The concentration was probably higher, because the particle counter used in the study saturates at $1 \times 10^{6} \mathrm{~cm}^{-3}$. The portable CPC model 3007 used by the pedestrians may also have been saturated, with saturation at $1 \times 10^{5} \mathrm{~cm}^{-3}$, and, 
with the diluters, the maximum concentration measured was $\sim 3 \times 10^{5} \mathrm{~cm}^{-3}$. The maximum 1 min particle number concentration in the aerosol cottage during the experiment was $3.3 \times 10^{4} \mathrm{~cm}^{-3}$, an order of magnitude lower than the maxima measured by the pedestrians at some hundreds of meters further away from the burning area.

To get a quantitative estimate of the decrease of the number concentrations, an exponential function $N=N_{0} \mathrm{e}^{-k x}$ was fitted to the data, where $N_{0}$ is the background concentration, $x$ is the distance from the center of the burn area, and $k$ is the reciprocal of the e-folding distance $k^{-1}$. The fittings yielded e-folding distances of $98 \mathrm{~m}, 417 \mathrm{~m}$ and $833 \mathrm{~m}$ for the Sniffer, walker and aircraft data, respectively. The background particle number concentration at SMEAR II on that day was in the range of $1000-3000 \mathrm{~cm}^{-3}$ (Fig. 9b). This concentration was reached at $\sim 2 \mathrm{~km}$ from the burn area at ground level and at $\sim 5 \mathrm{~km}$ from the burn area in the airborne measurements. However, within approximately $1 \mathrm{~km}$ distance from the burn area (Fig. 15), the exponential form did not fit the aircraft data quite as well as a power law $N_{0} x^{-b}$. This suggests that a Gaussian formula is not necessarily the best option for describing the dilution of smoke in the immediate vicinity of forest fires.

\subsection{Changes in soil properties, greenhouse gas and VOC fluxes}

The clear-cutting and burning of slash increased soil temperature and moisture, soil $\mathrm{pH}$, and $\mathrm{NH}_{4}-\mathrm{N}$ and $\mathrm{NO}_{3}-\mathrm{N}$ concentrations (Kulmala et al., 2014). The increase in the topsoil soil $\mathrm{pH}$ and mineral nitrogen concentrations $\left(\mathrm{NH}_{4}-\mathrm{N}\right.$ and $\mathrm{NO}_{3}-\mathrm{N}$ ) were rapid, response times ranging from days to a few months, whereas the changes in the deep-soil $\mathrm{pH}$ and nitrogen contents were much smaller and were observed with a delay of one to two years. In contrast, the total available nitrogen concentration did not increase after the clear-cutting and burning, but the proportion of mineral nitrogen $\left(\mathrm{NH}_{4}-\mathrm{N}\right.$ and $\mathrm{NO}_{3}-\mathrm{N}$ ) of the total increased dramatically (Kulmala et al., 2014).

The rates of soil $\mathrm{CO}_{2}$ efflux at the sites were similar before the clear-cut and burning of slash. After the treatment, the efflux at the burned site was approximately only half of the flux at the control site (Kulmala et al., 2014). Two years later, the difference between the burned clear-cut and the mature control forest had decreased. The cumulative soil $\mathrm{CO}_{2}$ emissions during 2009-2011, interpolated from the chamber measurements and excluding winter months, were the highest at the clear-cut but not at the burned site. Nevertheless, taking into account the rapid $\mathrm{CO}_{2}$ release during the burning, the burned clear-cut site had the highest $\mathrm{CO}_{2}$ emissions over the $3 \mathrm{yr}$ period (Kulmala et al., 2013)

Before and after the clear-cut and burning, all three sites acted as $\mathrm{CH}_{4}$ sinks. Similar to the $\mathrm{CO}_{2}$ exchange, the soil uptake of $\mathrm{CH}_{4}$ decreased significantly soon after the burning. Burning did not seem to have a long-term effect on soil
$\mathrm{CH}_{4}$ uptake as the differences between the three sites disappeared during the following years (Kulmala et al., 2013). The decrease in soil $\mathrm{CH}_{4}$ uptake after clear-cutting and burning may be related to changes in soil temperature and moisture and to the increased soil $\mathrm{NH}_{4}-\mathrm{N}$ content, as mineral nitrogen in the soil may inhibit $\mathrm{CH}_{4}$ oxidation (Saari et al. 1997, 2004; Maljanen et al., 2006).

The soil VOC emissions were generally low compared to the total VOC emissions from similar forest ecosystems. This result is also in line with the general finding that the forest floor makes up a maximum of $\sim 10 \%$ of the total ecosystem VOC emissions in coniferous forest (Hayward et al., 2001; Hakola et al., 2006; Taipale et al., 2008, 2009). The VOC fluxes between the chambers differed greatly at the burned site, which is a phenomenon often observed with forest-floor VOC flux measurements (Aaltonen et al., 2011). After one year, the emissions of VOCs had nearly stabilized close to the level before the burning.

\section{Summary and conclusions}

The general goal of the prescribed fire experiment on 26 June 2009 in Hyytiälä, Finland, was to collect data for estimating the effect of prescribed fires burning slash fuels on air quality and climate. The experiment was designed from the beginning to be multidisciplinary, and it had several more detailed goals: to obtain emission factors of aerosols and gases from boreal wildfires, to characterize the climatically relevant physical properties of the smoke aerosol, to quantify the connections between ground-based smoke observations and satellite remote sensing, to obtain data for testing an improved model of atmospheric dispersion of the fire plume, and to quantify the changes taking place in soil carbon stocks and greenhouse gas fluxes following clear-cutting and prescribed burning.

In the campaign, a 0.8 ha region of forest near the SMEAR II was cut clear, and some tree trunks, all treetops and all branches were left on the ground and burned. The amount of burned organic material was estimated to be about 46.8 tons (i.e., about 60 tons ha $^{-1}$ ), of which $64 \%$ consisted of the cut tree material, $32 \%$ of organic litter and humus layer and $4 \%$ of surface vegetation.

During the burning, various measurements were conducted on the ground with both fixed and mobile instrumentation, and from a research aircraft. Most of the time the smoke was not transported to the SMEAR II station due to the low wind speed or calm meteorological conditions that were associated with substantial, sudden variations of the wind direction. The low wind speeds in combination with the substantial buoyancy of the fire plumes resulted in an almost vertical rise of a substantial fraction of the effluents. The fire was started when the wind was from the right direction in terms of the main measuring stations, but the wind direction soon turned. The ideal wind direction to bring smoke to 
SMEAR II would have been $190 \pm 10^{\circ}$, whereas the average wind direction was $134-140^{\circ}$ at all levels of the SMEAR II $73 \mathrm{~m}$ mast. Therefore, the smoke plumes were located west of the station, and the smoke reached the sample line inlets of the instruments at SMEAR II only during short periods.

In a related article (Kukkonen et al., 2014), we have presented an overview of a mathematical model, BUOYANT, that was designed for the evaluation of the dispersion of buoyant plumes. We have compared model predictions with the data of (i) the SCAR-C experiment in Quinault (US) in 1994 (e.g., Kaufman et al., 1996; Hobbs et al., 1996; Gassó and Hegg, 1998), and (ii) the prescribed burning experiment addressed in this article. In the case of the latter experiment, the model predictions were compared with plume elevations and diameters, determined based on particulate matter number concentration measurements on board an aeroplane. The agreement of modeled and measured results was good for both of these experiments, provided that in the case of the Hyytiälä prescribed burning, one assumes the measured maximum convective heat fluxes as input data for the model. The results demonstrated that in both cases there were substantial uncertainties in estimating (i) the source terms for the atmospheric dispersion computations, and (ii) the relevant vertical meteorological profiles. The burnt area in the Quinault experiment was substantially larger, approximately 20 ha, than the 0.8 ha in our experiment. Correspondingly, the maximum convective heat flux in the Quinault experiment was clearly higher than that in the Hyytiälä experiment (Kukkonen et al., 2014). The meteorological conditions were also substantially different in these two experiments; there was an elevated inversion in the case of the Quinault experiment. The plume in the Hyytiälä experiment ascended to higher altitudes compared with that in the Quinault experiment, according to both the measurements and the model predictions (Kukkonen et al., 2014). This was mainly caused by the different vertical structure of the atmosphere, especially the temperature inversion in the Quinault case.

Despite the changing of the wind direction and the intensive plume rise, concentrations originating from the fire were detected both from within the burn area and part of the time also at the ground-based stations. In the middle of the burning area, $\mathrm{CO}_{2}$ concentration peaks were around 2000$3000 \mathrm{ppm}$ above the baseline, and peak vertical flow velocities were $6 \pm 3 \mathrm{~m} \mathrm{~s}^{-1}$. The meteorological stations placed near the perimeter of the burn area produced data for the analysis of fire dynamics. A strong rise in moisture was observed in the plume, which has been suggested as possibly modifying plume dynamics.

The concentrations of the trace gases $\mathrm{O}_{3}, \mathrm{NO}_{\mathrm{x}}, \mathrm{SO}_{2}, \mathrm{CO}$ and $\mathrm{CO}_{2}$, which are routinely measured from six different altitudes in the mast, should be elevated in a biomass-burning plume. The most distinct exceedances above the background values were for $\mathrm{CO}, \mathrm{NO}_{\mathrm{x}}$ and $\mathrm{SO}_{2}$, but no obvious smokeplume-related variations were observed for $\mathrm{O}_{3}$ and $\mathrm{CO}_{2}$. The lack of a signal in the $\mathrm{CO}_{2}$ measurements may indicate that the sensitivity or the response time of the $\mathrm{CO}_{2}$ monitor was not sufficient. Even though the $\mathrm{CO}_{2}$ concentrations did not rise, there were several other indicators of smoke arriving from the burning biomass: elevated particle number concentrations, higher scattering coefficients, elevated CO concentrations, and elevated concentrations of many VOCs that are known to be emitted during biomass burning. They were detected almost simultaneously with the elevated CO concentrations, so linear regressions were calculated between excess concentrations of VOCs and CO. For most of the compounds, the emission ratios (defined as $\Delta \mathrm{X} / \Delta \mathrm{CO}$ ) in the present study are larger than those in other studies presented on boreal forest fires. The values for formaldehyde were smaller, and values for monoterpenes were close to other published ratios. The reason for the larger emission ratios may either be a true difference or artefact due to the non-collocated measurements of the VOCs and CO. If it were a true difference, it would mean that the biomass burned is different from that burned by Akagi et al. (2011) and Simpson et al. (2011). Further studies are needed to confirm either of these hypotheses.

Peak particle number concentrations were approximately $1-2 \times 10^{6} \mathrm{~cm}^{-3}$ in the plume at the distance of $100-200 \mathrm{~m}$ from the burn area on the ground and in the research aircraft. At SMEAR II, the total particle number concentrations increased from about $1000-2000 \mathrm{~cm}^{-3}$ before the smoke arrived at the instrumentation to about $30000 \mathrm{~cm}^{-3}$ within the plume. The air ion measurements showed that cluster-mode and intermediate-mode ions were depleted in the strongest smoke plume passages, suggesting that the ions were attached to the larger aerosols in the plume. The maximum particle mass concentrations in the smoke plume observed in the aerosol cottage were $21.6 \mu \mathrm{g} \mathrm{m}^{-3}$ and $28.6 \mu \mathrm{g} \mathrm{m}^{-3}$ during the flaming and smoldering phases, respectively. It is worth noting that the latter peak was observed simultaneously with the highest $\mathrm{CO}$ peak and at time when the visual smoke emissions from the burn were clearly smaller than during the flaming phase.

In the number size distribution, there were 3-4 modes. The geometric mean diameter of the mode with the highest concentration was $80 \pm 1 \mathrm{~nm}$ during the flaming phase and in the middle of the smoldering phase. The mode diameters of the size distributions observed during the flaming phase were clearly smaller than those presented from similar experiments. A probable explanation is that the fires in the compared experiments were considerably larger than ours. For instance, Radke et al. (1991) measured size distributions in an aircraft in smoke plumes from prescribed fires where the burned areas were in the range of 10-700 ha (i.e., one to three orders of magnitude larger than in our experiment), and Hobbs et al. (1996) measured within fires of 20-40 ha. In those fires, the amount of burned biomass was much larger than in our experiment, so the smoke definitely also contained more condensable material to grow particles. At the end of the smoldering phase, the largest mode was $122 \mathrm{~nm}$, larger than during the flaming phase. In the volume size 
distributions, the geometric mean diameter of the largest volume mode was $153 \mathrm{~nm}$ during the flaming phase and $300 \mathrm{~nm}$ during the smoldering phase. In contrast to our observations, Hobbs et al. (1996), during the SCAR-C project, and Payne et al. (2004), during the ICFME, found that the mode diameter of the size distribution was smaller in the plume during the smoldering phase than during the flaming phase. Both of these observations were made in airborne measurements. One possible explanation to this very obvious discrepancy is that during the flaming phase the particles in the plume that was detected in the aerosol cottage were smaller than those in the main plume that ascended with the hot air. Unfortunately, it is not possible to prove or disprove this hypothesis because in our aircraft we did not measure particle size distributions.

The aerosol optical properties were in agreement with other published data from wildfire smoke aerosols. The particles were not dark; the lowest single-scattering albedo of the ground-level measurements was 0.7 in the flaming-phase plume and $\sim 0.9$ in the smoldering phase. The mass scattering efficiency of $4.1-4.3 \mathrm{~m}^{2} \mathrm{~g}^{-1}$ at $\lambda=550 \mathrm{~nm}$ is also in agreement with other published wildfire aerosol data.

There were changes in soil physical and chemical properties, which influenced the soil greenhouse gas $\left(\mathrm{CO}_{2}, \mathrm{CH}_{4}\right)$ fluxes for several years after the burning. The VOC fluxes were generally low and consisted mainly of monoterpenes, but a clear peak was observed after the burning. One year after the burning, the fluxes had nearly stabilized close to the level before the burning.

The discussion above shows that some of the goals of the experiment were reached, some were not. The emission factors of aerosols and gases could not be obtained because most of the smoke did not reach the instrumentation. The climatically relevant physical properties of the smoke aerosol were partially obtained, but the lack of aerosol optical depth data and hygroscopic growth factors prevent an estimate of the smoke-aerosol-climate-forcing effect. The quantification of the connections between ground-based smoke observations and satellite remote sensing failed because the smoke was not detected in any satellite images. The MODIS onboard the Terra and Aqua platforms made two overpasses of the site shortly after the fire but no signs of the forest fire plume were observed. This is not a unique case: the global number of fires so small that they cannot be observed with MODIS is not well known but their contribution to biomass burning emissions has lately been estimated to be considerable (Randerson et al., 2012).

The plan was successful in that we obtained data for testing and improved models of atmospheric dispersion of the fire plume, data on the recovery of the forest after burning, and data of the changes taking place in soil-carbon stocks and greenhouse gas fluxes following clear-cutting and prescribed burning. The airborne measurements have already been used for evaluating and refining of a plume-rise model (Kukkonen et al., 2014). The data are available also for the evaluation of other corresponding models.
The experiment taught us several lessons. First, the selection of the meteorological conditions is critical for the success of the experiment. In particular, a higher wind speed that would result in a more inclined plume would be more suitable with regard to the ground-based measurements. However, we had to set an upper limit of $5 \mathrm{~m} / \mathrm{s}$ for the wind speed at $10 \mathrm{~m}$ height, for safety reasons. There were also several other requirements, especially regarding the wind direction, that limited the choice of a suitable date. We selected the burning site so that the measurement stations were almost in the direction of the prevailing winds (southwesterly). According to the climatological survey conducted before the experiment, favorable conditions would most likely occur several times within the selected two-month period (May and June of 2009). However, unluckily, the acceptable conditions did not occur until 26 June.

Second, we would recommend more mobile platforms to ensure good measurements of the fire plumes, even in situations in which the wind direction unexpectedly changes. Airborne measurements of particles and trace gases are especially useful for measuring the dispersion of strongly buoyant, almost vertically rising smoke plumes released from wildfires and prescribed fires. In large natural wildfires, a wide range of aircraft with instruments for measuring aerosol optical properties, size distributions, chemical composition and trace gases can be used for such measurements. However, in a small prescribed fire, such as the present experiment, the plume was so narrow that even a small aircraft flew through it in about $3 \mathrm{~s}$ at the lowest altitude levels and in about 30 seconds even at the widest plume crossings. The aircraft data obtained was useful; however, the short measurement time and the small aircraft size also had limitations. For instance, the above-mentioned time intervals are too short for measuring some advanced properties, for example the hygroscopic growth of particles. Using a helicopter would enable us to fly more slowly through the smoke plume; however, a helicopter also needs to have a sufficient forward speed to avoid the rotor downwash effects (e.g., Cofer III et al., 1998).

Third, in fire experiments the response time of all measurements should be set as fast as possible. In our experiment some trace gas and aerosol instruments were not operating at the fastest response time and this compromised some of our results.

Fourth, visual documentation of the phases of prescribed fires is important for the interpretation of the experiment. Even standard photographs proved to be valuable but more information could have been obtained with video surveillance at both visible and infrared wavelengths. In our experiment it was not arranged but it would have given better information for instance on flame height, fire spread, and temperature. 
Acknowledgements. The financial support by the Academy of Finland as part or the Centre of Excellence program (project no. 1118615) and as part of the IS4FIRES project (decision no. 122870) is gratefully acknowledged. The experiment was also supported by the European Commission 6th Framework Program Project (EUCAARI), contract 036833-2; the European Research Council; the University of Helsinki; the Finnish Meteorological Institute; the Academy of Finland; the TEKES (project KASTU, decision no. 40208/08 and KASTU-2, decision no. 40393/10); San José State University, CA, USA; and the Institute for Tropospheric Research, Leipzig, Germany. J. Pumpanen was funded by Academy of Finland project number 218094. Partial funding for D. M. Schultz came from Vaisala Oyj. We gratefully acknowledge the help given by the personnel of SMEAR II.

Edited by: S. M. Noe

\section{References}

Aalto, P., Hämeri, K., Becker, E., Weber, R., Salm, J., Mäkelä, J. M., Hoell, C., O’Dowd, C.D., Karlsson, H., Hansson, H.-C., Väkevä, M., Koponen, I. K., Buzorius, G., and Kulmala, M.: Physical characterization of aerosol particles during nucleation events, Tellus, 53B, 344-358, 2001.

Aaltonen, H., Pumpanen, J., Pihlatie, M., Hakola, H., Hellén, H., Kulmala, L., Vesala, T., and Bäck, J.: Boreal pine forest floor biogenic volatile organic compound emissions peak in early summer and autumn, Agr. Forest Meteorol., 151, 682-691, 2011.

Achtemeier, G. L.: Measurements of moisture in smouldering smoke and implications for fog, Int. J. Wildl. Fire, 15, 517-525, 2006.

Akagi, S. K., Yokelson, R. J., Wiedinmyer, C., Alvarado, M. J., Reid, J. S., Karl, T., Crounse, J. D., and Wennberg, P. O.: Emission factors for open and domestic biomass burning for use in atmospheric models, Atmos. Chem. Phys., 11, 4039-4072, doi:10.5194/acp-11-4039-2011, 2011.

Alexander, M. E.: Prescribed burn documentation and fire danger ratings: a case study, edited by: Viegas, D. X., Proceedings of the 5th International Conference on Forest Fire Research, 2730 November 2006, Figueira da Foz, Portugal, Elsevier, Amsterdam, 12 pp., 2006.

Alexander, M. E.: Fire behavior in moderately heavy logging slash: documenting the past with photographs, edited by: D. X. Viegas, Proceedings of the 6th International Conference on Forest Fire Research, 15-18 November 2010, Coimbra, Portugal. University of Coimbra, Coimbra, Portugal. 12 pp., 2010.

Alexander, M. E. and Thomas, D. A.: Prescribed fire case studies, decision aids, and planning guides, Fire Management Today, 66, 5-20, 2006.

Alexander, M. E., Stefner, C. N., Mason, J. A., Stocks, B. J., Hartley, G. R., Maffey, M. E., Wotton, B. M., Taylor, S. W., Lavoie, N., and Dalrymple, G. N.: Characterizing the jack pine black spruce fuel complex of the International Crown Fire Modelling Experiment (ICFME). Canadian Forest Service Northern Forestry Centre Information Report NOR-X-393, 2004.

AMAP 2011: The Impact of Black Carbon on Arctic Climate, edited by: Quinn, P. K., Stohl, A., Arneth, A., Berntsen, T., Burkhart, J. F., Christensen, J., Flanner, M., Kupiainen, K., Lihavainen, H., Shepherd, M., Shevchenko, V., Skov, H., and Vestreng, V., Arctic
Monitoring and Assessment Programme (AMAP), Oslo, 72 pp., 2011.

Andreae, M. and Merlet, P.: Emission of trace gases and aerosols from biomass burning, Global Biogeochem. Cy., 15, 955-966, 2001.

Andrews, E., Sheridan, P. J., Fiebig, M., McComiskey, A., Ogren, J. A., Arnott, P., Covert, D., Elleman, R., Gasparini, R., Collins, D., Jonsson, H., Schmid, B., and Wang, J.: Comparison of methods for deriving aerosol asymmetry parameter. J. Geophys. Res., 111, D05S04, doi:10.1029/2004JD005734, 2006.

Arnott, W. P., Hamasha, K., Moosmüller, H., Sheridan, P. J., Ogren, J. A.: Towards aerosol light-absorption measurements with a 7wavelength aethalometer: evaluation with a photoacoustic instrument and 3-wavelength nephelometer, Aerosol Sci. Technol. 39, 17-29, 2005.

Asmi, E., Sipilä, M., Manninen, H. E., Vanhanen, J., Lehtipalo, K., Gagné, S., Neitola, K., Mirme, A., Mirme, S., Tamm, E., Uin, J., Komsaare, K., Attoui, M., and Kulmala, M.: Results of the first air ion spectrometer calibration and intercomparison workshop, Atmos. Chem. Phys., 9, 141-154, doi:10.5194/acp-9-141-2009, 2009.

Bond, T. C. and Bergstrom, R. W.: Light absorption by carbonaceous particles: An investigative review, Aerosol Sci. Technol., 40, 27-67, 2006.

Bond, T. C., Doherty, S. J., Fahey, D. W., Forster, P. M., Berntsen, T., DeAngelo, B. J., Flanner, M. G., Ghan, S., Kärcher, B., Koch, D., Kinne, S., Kondo, Y., Quinn, P. K., Sarofim, M. C., Schultz, M. G., Schulz, M., Venkataraman, C., Zhang, H., Zhang, S., Bellouin, N., Guttikunda, S. K., Hopke, P. K., Jacobson, M. Z., Kaiser, J. W., Klimont, Z., Lohmann, U., Schwarz, J. P., Shindell, D., Storelvmo, T., Warren, S. G., and Zender, C. S.: Bounding the role of black carbon in the climate system: A scientific assessment, J. Geophys. Res., 118, 5380-5552, doi:10.1002/jgrd.50171, 2013.

Bowman, D. M. J. S., Balch, J. K., Artaxo, P., Bond, W. J., Carlson, J. M., Cochrane, M. A., D’Antonio, C. M., DeFries, R. S., Doyle, J. C., Harrison, S. P., Johnston, F. H., Keeley, J. E., Krawchuk, M. A., Kull, C. A., Marston, J. B., Moritz, M. A., Prentice, I. C., Roos, C. I., Scott, A. C., Swetnam, T. W., van der Werf, G. R., and Pyne, S. J.: Fire in the Earth System, Science 324, 481-484, 2009.

Bowman, D., Balch, J., Artaxo, P., Bond, W., Cochrane, M., D’Antonio, C., DeFries, R., Johnston F., Keeley, J., Krawchuk, M., Kull, C., Mack, M., Moritz, M., Pyne, S., Roos, C., Scott, A., Sodhi, N., and Swetnam, T.: The human dimension of fire regimes on Earth, J. Biogeogr., 38, 2223-2236, 2011.

Cahill, C. F., Cahill, T. A., and Perry, K. D.: The size- and timeresolved composition of aerosols from a sub-Arctic boreal forest prescribed burn, Atmos. Environ., 42, 7553-7559, 2008.

Clements, C. B., Potter, B. E., and Zhong, S.: In situ Measurements of Water Vapor, Heat and $\mathrm{CO}_{2}$ Fluxes within a prescribed Grass Fire. International Journal of Wildland Fire, 15, 299-306, 2006.

Clements, C. B., Zhong, S., Goodrick, S., Li, J., Bian, X., Potter, B. E., Heilman, W. E., Charney, J. J., Perna, R., Jang, M., Lee, D., Patel, M., Street, S., and Aumann, G.: Observing the dynamics of wildland grass fires: FireFlux - a field validation experiment, B. Am. Meteorol. Soc., 88, 1369-1382, 2007. 
Clements, C.B., Zhong, S., Bian, X., Heilman, W., and Byun, D.: First observations of turbulence generated by grass fire, J. Geophys. Res. 113, D22102, doi:10.1029/2008JD010014, 2008.

Coen, J., Mahalingam, S., and Daily, J.: Infrared imagery of crownfire dynamics during FROSTFIRE, J. Appl. Meteorol. 43, 12411259, 2004.

Cofer III, W. R., Winstead, E. L., Stocks, B. J., Goldammer, J. G., and Cahoon, D. R.: Crown fire emissions of $\mathrm{CO}_{2}, \mathrm{CO}, \mathrm{H}_{2}, \mathrm{CH}_{4}$, and TNMHC from a dense jack pine boreal forest fire. Geophys. Res. Lett. 25, 3919-3922, 1998.

Conny, J. M. and Slater, J. F.: Black carbon and organic carbon in aerosol particles from crown fires in the Canadian boreal forest, J. Geophys. Res., 107, 10.1029/2001JD001528, 2002.

Cross, E. S., Onasch, T. B., Ahern, A., Wrobel, W., Slowik, J., Olfert, J., Lack, D., Massoli, P., Cappa, C., Schwarz, J., Spackman, R., Fahey, D., Sedlacek, A., Trimborn, A., Jayne, J., Freedman, A., Williams, L., Ng, N. L., Mazzoleni, C., Dubey, M., Brem, B., Kok, G., Subramanian, R., Freitag, S., Clarke, A., Thornhill, D., Marr, L., Kolb, C., Worsnop, D., and Davidovits, P.: Soot Prticle Studies - Instrument Inter-Comparison - Project Overview, Aerosol Sci. Technol., 44, 592-611, 2010.

Dal Maso, M., Kulmala, M., Riipinen, I., Wagner, R., Hussein, T., Aalto, P. P., and Lehtinen, K. E. J.: Formation and growth of fresh atmospheric aerosols: eight years of aerosol size distribution data from SMEAR II, Hyytiälä, Finland, Boreal Environ. Res., 10, 323-336, 2005.

de Gouw, J. and Warneke, C.: Measurements of volatile organic compounds in the earth's atmosphere using proton-transferreaction mass spectrometry, Mass Spectrom. Rev., 26, 223-257, doi:10.1002/mas.20119, 2007.

Delene, D. J. and Ogren, J. A.: Variability of Aerosol Optical Properties at Four North American Surface Monitoring Sites, J. Atmos. Sci., 59, 1135-1150, 2002.

Drewnick, F., Hings, S. S., DeCarlo, P., Jayne, J. T., Gonin, M., Fuhrer, K., Weimer, S., Jimenez, J. L., Demerjian, K. L., Borrmann, S., and Worsnop, D. R.: A new time-of-flight aerosol mass spectrometer (TOF-AMS) - Instrument description and first field deployment. Aerosol Sci. Technol., 39, 637-658, 2005.

Ferguson, S. A., Collins, R. L., Ruthford, J., and Fukuda, M.: Vertical distribution of nighttime smoke following a wildland biomass fire in boreal Alaska, J. Geophys. Res., 108, 4743, doi:10.1029/2002JD003324, 2003

Finnish Forest Research Institute: Yearbook of Forest Statistics 1990-1991, 1991.

Finnish Forest Research Institute: Finnish Statistical Yearbook of Forestry 2011, 2011.

FIRESCAN Science Team: Fire in ecosystems of Boreal Eurasia: the Bor Forest Island Fire Experiment, Fire Research Campaign Asia-North (FIRESCAN), edited by: Levine, J. S., Biomass burning and global change, volume 2: biomass burning in South America, Southeast Asia, and temperate and boreal ecosystems, and the oil fires of Kuwait, MIT Press, Cambridge, Mass., 848873. 1996.

Flannigan, M. D. and Haar, T. V.: Forest fire monitoring using NOAA satellite AVHRR. Canad. J. Forest Res., 16, 975-982, 1986.

French, N. H., Kasischke, E. S., Hall, R. J., Murphy, K. A., Verbyla, D. L., Hoy, E. E., and Allen, J. L.: Using Landsat data to assess fire and burn severity in the North American boreal forest region: an overview and summary of results, Int. J. Wildl. Fire, 17, 443462, 2008.

Gassó, S. and Hegg, D. A.: Comparison of columnar aerosol optical properties measured by the MODIS airborne simulator with in situ measurements: A case study, Remote Sens. Environ., 66, 138-152, 1998.

Giglio, L., Randerson, J. T., van der Werf, G. R., Kasibhatla, P. S., Collatz, G. J., Morton, D. C., and DeFries, R. S.: Assessing variability and long-term trends in burned area by merging multiple satellite fire products, Biogeosciences, 7, 1171-1186, doi:10.5194/bg-7-1171-2010, 2010.

Goldammer, J. G. and Furyaev, V. V.: Fire in ecosystems of boreal Eurasia: Ecological impacts and links to the global system, in Fire in Ecosystems of Boreal Eurasia, edited by: Goldammer, J. G. and Furyaev, V. V., 1-20, Kluwer Acad., Norwell, Mass., 1996.

Grell, G., Freitas, S. R., Stuefer, M., and Fast, J.: Inclusion of biomass burning in WRF-Chem: impact of wildfires on weather forecasts, Atmos. Chem. Phys., 11, 5289-5303, doi:10.5194/acp11-5289-2011, 2011.

Hakola, H., Tarvainen, V., Back, J., Ranta, H., Bonn, B., Rinne, J., and Kulmala, M.: Seasonal variation of mono- and sesquiterpene emission rates of Scots pine. Biogeosciences, 3, 93-101, doi:10.5194/bg-3-93-2010, 2006.

Hari, P. and Kulmala, M.: Station for measuring ecosystematmosphere relations (SMEAR II), Boreal Env. Res. 10, 5, 315322, 2005.

Hayward, S., Muncey, R. J., James, A. E., Halsall, C. J., and Hewitt, C. N.: Monoterpene emissions from soil in a Sitka spruce forest, Atmos. Environ., 35, 4081-4087, 2001.

Haywood, J. M. and Shine, K. P.: The effect of anthropogenic sulfate and soot aerosol on the clear sky planetary radiation budget, Geophys. Res. Lett., 22, 603-606, 1995.

Heikinheimo, O.: Kaskiviljelyksen vaikutus Suomen metsiin, Acta Forestalia Fennica 4, 1-264, 1-149 (appendix) and 1-59 (Summary), in Finnish with German summary, 1915.

Hewitt, C. N., Hayward, S., and Tani, A.: The application of proton transfer reaction-mass spectrometry (PTR-MS) to the monitoring and analysis of volatile organic compounds in the atmosphere, J. Environ. Monit., 5, 1-7, 2003.

Hinzman, L., Fukuda, M., Sandberg, D. V., Chapin III, F. S., and Dash, D.: FROSTFIRE: An experimental approach to predicting the climate feedbacks from the changing boreal fire regime, J. Geophys. Res., 108, 8153, doi:10.1029/2001JD000415, 2003.

Hirdman, D., Sodemann, H., Eckhardt, S., Burkhart, J. F., Jefferson, A., Mefford, T., Quinn, P. K., Sharma, S., Ström, J., and Stohl, A.: Source identification of short-lived air pollutants in the Arctic using statistical analysis of measurement data and particle dispersion model output, Atmos. Chem. Phys., 10, 669-693, doi:10.5194/acp-10-669-2010, 2010.

Hobbs, P. V., Reid, J. S., Herring, J. A., Nance, J. D., Weiss, R. E., Ross, J. L., Hegg, D. A., Ottmar, R. D., and Liousse, C.: Particle and trace-gas measurements in smoke from prescribed burns of forest products in the Pacific Northwest, in: Biomass Burning and Global Change, Vol. 1, edited by: Levine, J. S., 697-715, MIT Press, New York, 1006, 1996.

Hobbs, P. V., Sinha, P., Yokelson, R. J., Christian, T. J., Blake, D. R., Gao, S., Kirchstetter, T. W., Novakov, T., and Pilewskie, P.: 
Evolution of gases and particles from a savanna fire in South Africa. J. Geophys. Res., 108, SAF 21-1-SAF 21-20, 2003.

Jaffe, D. A. and Widger, N. L.: Ozone production from wildfires: A critical review, Atmos. Environ., 51, 1-10, 2012.

Janhäll, S., Andreae, M. O., and Pöschl, U.: Biomass burning aerosol emissions from vegetation fires: particle number and mass emission factors and size distributions, Atmos. Chem. Phys., 10, 1427-1439, doi:10.5194/acp-10-1427-2010, 2010.

Jayne, J. T., Leard, D. C., Zhang, X., Davidovits, P., Smith, K. A., Kolb, C. E., and Worsnop, D. R.:. Development of an aerosol mass spectrometer for size and composition analysis of submicron particles, Aerosol Sci. Technol., 33, 49-70, 2000.

Jimenez, J. L., Jayne, J. T., Shi, Q., Kolb, C. E., Worsnop, D. R., Yourshaw, I., Seinfeld, J.H., Flagan, R. C., Zhang, X., Smith, K. A., Morris, J. W., and Davidovits, P.: Ambient aerosol sampling using the Aerodyne Aerosol Mass Spectrometer, J. Geophys Res., 108, 8425, doi:10.1029/2001JD001213, 2003.

Johnston, F. H., Henderson, S. B., Chen, Y., Randerson, J. T., Marlier, M., DeFries, R. S., Kinney, P., Bowman, D. M. J. S., and Brauer, M.: Estimated global mortality attributable to smoke from landscape fires, Environ. Health Perspect., 120, 695-701, doi:10.1289/ehp.1104422, 2012.

Kaufman, Y. J., Remer, L. ., Ottmar, R. D., Ward, D. E., Li, R.R., Kleidman, R., Fraser, R. S., Flynn, L., McDougal, D., and Shelton, G.: Relationship between remotely sensed fire intensity and rate of emission of smoke: SCAR-C experiment, in: Biomass Burning and Global Change, edited by: Levine, J. S., MIT Press, Cambridge, MA, 685-696, 1996.

Keskinen, J., Pietarinen, K., and Lehtimäki, M.: Electrical low pressure impactor. J.Aerosol Sci., 23, 353-360, 1992.

Kiefer, C. M., Clements, C. B., and Potter, B. E.: Application of a Mini-Unmanned Aircraft System for In situ Monitoring of Fire Plume Thermodynamics Properties, Journal of Atmospheric and Oceanic Technology, 29, 309-315, 2012

Klein, T., Kukkonen, J., Dahl, Å, Bossioli, E., Baklanov, A., Vik, A. F., Agnew, P., Karatzas, K. D., and Sofiev, M.: Interactions of Physical, Chemical, and Biological Weather Calling for an Integrated Approach to Assessment, Forecasting, and Communication of Air Quality. Ambio, 41, 851-864, doi:10.1007/s13280012-0288-z, 2012.

Kukkonen, J., Nikmo, J., Sofiev, M., Riikonen, K., Petäjä, T., Virkkula, A., Levula, J., Schobesberger, S., and Webber, D. M.: Applicability of an integrated plume rise model for the dispersion from wild-land fires, Geosci. Model Dev. Discuss., 7, 483-527, doi:10.5194/gmdd-7-483-2014, 2014.

Kulmala, L., Pumpanen, J., Pohja, T., Laakso, H., Siivola, E., Hari, P., and Vesala, T.: A novel automatic chamber to measure soil CO2 efflux, Rep. Ser. Aerosol Sci., 109, http://www.atm.helsinki.fi/FAAR/reportseries/rs-109/abstracts/ LiisaKulmala.pdf, 2010.

Kulmala, L., Aaltonen, H., Berninger, F., Kieloaho, A.-J., Levula, J., Bäck, J., Hari, P., Kolari, P., Korhonen J.F.J., Kulmala, M., Nikinmaa, E., Pihlatie, M., Vesala, T., and Pumpanen, J.: Changes in biogeochemistry and carbon fluxes in a boreal forest after the clear-cutting and partial burning of slash, Agric. Forest Meteorol., 188, 33-44, 2014.

Kulmala, M., Asmi, A., Lappalainen, H. K., Baltensperger, U., Brenguier, J.-L., Facchini, M. C., Hansson, H.-C., Hov, Ø., O’Dowd, C. D., Pöschl, U., Wiedensohler, A., Boers, R.,
Boucher, O., de Leeuw, G., Denier van der Gon, H. A. C., Feichter, J., Krejci, R., Laj, P., Lihavainen, H., Lohmann, U., McFiggans, G., Mentel, T., Pilinis, C., Riipinen, I., Schulz, M., Stohl, A., Swietlicki, E., Vignati, E., Alves, C., Amann, M., Ammann, M., Arabas, S., Artaxo, P., Baars, H., Beddows, D.C. S., Bergström, R., Beukes, J. P., Bilde, M., Burkhart, J. F., Canonaco, F., Clegg, S. L., Coe, H., Crumeyrolle, S., D’Anna, B., Decesari, S., Gilardoni, S., Fischer, M., Fjaeraa, A. M., Fountoukis, C., George, C., Gomes, L., Halloran, P., Hamburger, T., Harrison, R. M., Herrmann, H., Hoffmann, T., Hoose, C., Hu, M., Hyvärinen, A., Hõrrak, U., Iinuma, Y., Iversen, T., Josipovic, M., Kanakidou, M., Kiendler-Scharr, A., Kirkevåg, A., Kiss, G., Klimont, Z., Kolmonen, P., Komppula, M., Kristjánsson, J.-E., Laakso, L., Laaksonen, A., Labonnote, L., Lanz, V. A., Lehtinen, K. E. J., Rizzo, L. V., Makkonen, R., Manninen, H. E., McMeeking, G., Merikanto, J., Minikin, A., Mirme, S., Morgan, W. T., Nemitz, E., O’Donnell, D., Panwar, T. S., Pawlowska, H., Petzold, A., Pienaar, J. J., Pio, C., Plass-Duelmer, C., Prévõt, A. S. H., Pryor, S., Reddington, C. L., Roberts, G., Rosenfeld, D., Schwarz, J., Seland, Ø., Sellegri, K., Shen, X. J., Shiraiwa, M., Siebert, H., Sierau, B., Simpson, D., Sun, J. Y., Topping, D., Tunved, P., Vaattovaara, P., Vakkari, V., Veefkind, J. P., Visschedijk, A., Vuollekoski, H., Vuolo, R., Wehner, B., Wildt, J., Woodward, S., Worsnop, D. R., van Zadelhoff, G.-J., Zardini, A. A., Zhang, K., van Zyl, P. G., Kerminen, V.-M., S Carslaw, K., and Pandis, S. N.: General overview: European Integrated project on Aerosol Cloud Climate and Air Quality interactions (EUCAARI) - integrating aerosol research from nano to global scales, Atmos. Chem. Phys., 11, 13061-13143, doi:10.5194/acp11-13061-2011, 2011.

Lamarque, J. F., Bond, T. C., Eyring, V., Granier, C., Heil, A., Klimont, Z., Lee, D. S., Liousse, C., Mieville, A., Owen, B., Schultz, M., Shindell, D., Smith, S. J., Stehfest, E., van Aardenne, J., Cooper, O., Kainuma, M., Mahowald, N., McConnell, J. R., Riahi, K., and Van Vuuren, D. P.: Historical (1850-2000) gridded anthropogenic and biomass burning emissions of reactive gases and aerosols: methodology and application, Atmos. Chem. Phys., 10, 7017-7039, doi:10.5194/acp-10-7017-2010, 2010.

Lavoué, D., Liousse, C., Cachier, H., Stocks, B. J., and Goldammer, J.: Modeling of carbonaceous particles emitted by boreal and temperate wildfires at northern latitudes, J. Geophys. Res., 105, 26871-26890, 2000.

Law, K. S. and Stohl, A.: Arctic Air Pollution: Origins and Impacts, Science 315, 1537, doi:10.1126/science.1137695, 2007.

Lemberg, T. and Puttonen, P.: Kulottajan käsikirja, Metsälehti Kustannus, Vammalan kirjapaino Oy, Finland. ISBN 952-5118-41-X, (In Finnish), 2002.

Lentile, L. B., Holden, Z. A., Smith, A. M., Falkowski, M. J., Hudak, A. T., Morgan, P., Lewis S. A., Gessler P. E., and Benson, N. C.: Remote sensing techniques to assess active fire characteristics and post-fire effects, Int. J. Wildl. Fire, 15, 319-345, 2006.

Maljanen, M., Jokinen, H., Saari, A., Strommer, R., and Martikainen, P.: Methane and nitrous oxide fluxes, and carbon dioxide production in boreal forest soil fertilized with wood ash and nitrogen. Soil Use Manage., 22, 151-157, 2006.

Malm, W. C. and Hand, J. L.: An examination of the physical and optical properties of aerosols collected in the IMPROVE program, Atmos. Environ., 41, 3407-3427, 2007. 
Manninen, H. E., Petäjä, T., Asmi, E., Riipinen, I., Nieminen, T., Mikkilä, J., Hõrrak, U., Mirme, A., Mirme, S., Laakso, L., Kerminen, V.-M., and Kulmala, M.: Long-term field measurements of charged and neutral clusters using Neutral cluster and Air Ion Spectrometer (NAIS), Boreal Environ. Res., 14, 591-605, 2009.

Marjamäki, M., Ntziachristos, L., Virtanen, A., Ristimäki, J., Keskinen,J., Moisio, M., Palonen, M., and Lappi, M.: Electrical Filter Stage for the ELPI, Society of Automotive Engineers (SAE) Technical Paper 2002-01-0055, 2002.

McMeeking, G. R., Kreidenweis, S. M., Baker, S., Carrico, C. M., Chow, J. C., Collet Jr., J. L., Hao, W. M., Holden, A. S., Kirchstetter, T. W., Malm, W. C., Moosmüller, H., Sullivan, A. P., and Wold, C. E.: Emissions of trace gases and aerosols during the open combustion of biomass in the laboratory, J. Geophys. Res., 114, D19210, doi:10.1029/2009JD011836, 2009.

McRae, D. J., Conard, S. G., Ivanova, G. A., Sukhinin, A. I., Baker, S. P., Samsonov, Y. N., Blake, T. W., Ivanov, V. A., Ivanov, A. V., Churkina, T. V., Hao, W. M., Koutzenogij, K. P., and Kovaleva, N.: Variability of fire behavior, fire effects, and emissions in scotch pine forests of Central Siberia, Mitigation and Adaptation Strategies for Global Change, 11, 45-74, doi:10.1007/s11027006-1008-4, 2006.

Mikhailov, E., Vlasenko, S., Podgorny, I., Ramanathan, V., and Corrigan, C.: Optical properties of soot-water drop agglomerates: An experimental study, J. Geophys. Res., 111, 1-16, 2006.

Naeher, L. P., Brauer, M., Lipsett, M., Zelikoff, J. T., Simpson, C. D., Koenig, J. Q., and Smith, K. R.: Woodsmoke health effects: A review, Inhal. Toxicol., 19, 67-106, doi:10.1080/08958370600985875, 2007.

National Interagency Fire Center: Fire information. Statistics for prescribed fire and wildland fire use fires, http://www.nifc. gov/fireInfo/fireInfo_statistics.html (last accessed 10 December 2012), 2011.

Paris, J.-D., Stohl, A., Nédélec, P., Arshinov, M. Yu., Panchenko, M. V., Shmargunov, V. P., Law, K. S., Belan, B. D., and Ciais, P.: Wildfire smoke in the Siberian Arctic in summer: Source characterization and plume evolution from airborne measurements, Atmos. Chem. Phys., 9, 9315-9327, doi:10.5194/acp-9-9315-2009, 2009.

Payne, N., Stocks, B. J., Robinson, A., Wasey, M., and Strapp, W.: Combustion aerosol from experimental crown fires in a boreal forest jack pine stand, Can. J. For. Res., 34, 1627-1633, 2004.

Pihlatie M., Christiansen, J.R., Aaltonen, H., Korhonen, J.F.J., Nordbo, A., Rasilo, T., Benanti, G., Giebels, M., Helmy, M., Sheehy, J., Jones, S., Juszczak, R., Klefoth, R., Lobo do Vale, R., Rosa, A.P., Schreiber, P., Serça, D., Vicca, S., Wolf B., and Pumpanen J.: Comparison of static chambers to measure $\mathrm{CH} 4$ emissions from soils. Agr. For. Met. 171-172, 124-136, 2013.

Pirjola, L., Parviainen, H., Hussein, T., Valli, A., Hämeri, K., Aalto, P., Virtanen, A., Keskinen, J., Pakkanen, T., Mäkelä, T., and Hillamo, R.: "Sniffer" - a novel tool for chasing vehicles and measuring traffic pollutants, Atmos. Environ., 38, 3625-3635, 2004.

Pirjola, L., Paasonen, P., Pfeiffer, D., Hussein, T., Hämeri, K., Koskentalo, T., Virtanen, A., Rönkkö, T., Keskinen, J., Pakkanen, T. A., and Hillamo, R. E.: Dispersion of particles and trace gases nearby a city highway: Mobile laboratory measurements in Finland, Atmos. Environ., 40, 867-879, 2006.
Potter, B. E.: The role of released moisture in the atmospheric dynamics associated with wildland fires. Int. J. Wildl. Fire, 14, 7784, doi:10.1071/WF04045, 2005.

Potter, B. E.: Atmospheric interactions with wildland fire behaviour - I. Basic surface interactions, vertical profiles and synoptic structures, Int. J. Wildl. Fire, 21, 779-801, doi:10.1071/WF11128, 2012.

Quinn, P. K., Bates, T. S., Baum, E., Doubleday, N., Fiore, A. M., Flanner, M., Fridlind, A., Garrett, T. J., Koch, D., Menon, S., Shindell, D., Stohl, A., and Warren, S. G.: Short-lived pollutants in the Arctic: their climate impact and possible mitigation strategies, Atmos. Chem. Phys., 8, 1723-1735, doi:10.5194/acp- 81723-2008, 2008.

Radke, L. F., Hegg, D. A., Hobbs, P. V., Nance, J. D., Lyons, J. H., Laursen, K. K., Weiss, R. E., Riggan, P. J., and Ward, D. E.: Particulate and trace gas emissions from large biomass fires in North America. Global Biomass Burning - Atmospheric, Climatic, and Biospheric Implications, edited by: Levine, J. S., 209-224, Cambridge, Mass, MIT Press, 1991.

Ramanathan, V. and Carmichael, G.: Global and regional climate changes due to black carbon, Nat. Geosci., 1, 221-227, 2008.

Randerson, J. T., Liu, H., Flanner, M. G., Chambers, S. D., Jin, Y., Hess, P. G., Pfister, G., Mack, M. C., Treseder, K. K., Welp, L. R., Chapin, F. S., Harden, J. W., Goulden, M. L., Lyons, E., Neff, J. C., Schuur, E. A. G., and Zender, C. S.: The impact of boreal forest fire on climate warming, Science, 314, 1130-1132, doi:10.1126/science.1132075, 2006.

Randerson, J. T., Chen, Y., van der Werf, G. R., Rogers, B. M., and Morton, D. C.: Global burned area and biomass burning emissions from small fires, J. Geophys. Res., 117, G04012, doi:10.1029/2012JG002128, 2012.

Reid, J. S., Koppmann, R., Eck, T. F., and Eleuterio, D. P.: A review of biomass burning emissions part II: intensive physical properties of biomass burning particles, Atmos. Chem. Phys., 5, 799825, doi:10.5194/acp-5-799-2005, 2005a.

Reid, J. S., Eck, T. F., Christopher, S. A., Koppmann, R., Dubovik, O., Eleuterio, D. P., Holben, B. N., Reid, E. A., and Zhang, J.: A review of biomass burning emissions part III: intensive optical properties of biomass burning particles. Atmos. Chem. Phys., 5, 827-849, doi:10.5194/acp-5-827-2005, 2005 b.

Repola, J., Ojansuu, R., and Kukkola, M.: Biomass functions for Scots pine, Norway spruce and birch in Finland Working Papers of the Finnish Forest Research Institute, 53, 28 pp., www. metla.fi/julkaisut/workingpapers/2007/mwp053.htm ISBN 978951-40-2046-9, 2007.

Saari, A., Martikainen, P., Ferm, A., Ruuskanen, J., De Boer, W., Troelstra, S., and Laanbroek, H. J.: Methane oxidation in soil profiles of Dutch and Finnish coniferous forests with different soil texture and atmospheric nitrogen deposition, Soil Biol. Biochem., 29, 1625-1632, 1997.

Saari, A., Rinnan, R., and Martikainen, P.J.: Methane oxidation in boreal forest soils: kinetics and sensitivity to $\mathrm{pH}$ and ammonium. Soil Biol. Biochem., 36, 1037-1046, 2004.

Saarikoski, S., Sillanpää, M., Sofiev, M., Timonen, H., Saarnio, K., Teinilä, K., Karppinen, A., Kukkonen, J., and Hillamo, R.: Chemical composition of aerosols during a major biomass burning episode over northern Europe in spring 2006: Experimental and modelling assessments, Atmos. Environ., 41, 3577-3589, 2007. 
Saarnio, K., Aurela, M., Timonen, H., Saarikoski, S., Teinilä, K., Mäkelä, T., Sofiev, M., Koskinen, J., Aalto, P. P., Kulmala, M., Kukkonen, J., and Hillamo, R.: Chemical composition of fine particles in fresh smoke plumes from boreal wild-land fires in Europe, Sci. Total Environ., 408, 2527-2542, 2010.

Schlesinger, W. H.: Biogeochemistry, an Analysis of Global Change, Academic Press, San Diego, USA, 588 pp., 1997.

Schobesberger, S., Väänänen, R., Leino, K., Virkkula, A., Backman, J., Pohja, T., Siivola, E., Franchin, A., Mikkilä, J., Paramonov, M., Aalto, P. P., Krejci, R., Petäjä, T., and Kulmala, M.: Airborne measurements over the boreal forest of southern Finland during new particle formation events in 2009 and 2010. Boreal Env. Res., 18, 145-163, 2013.

Schuster, G. L., Dubovik, O., and Holben, B. N.: Angstrom exponent and bimodal aerosol size distributions, J. Geophys. Res., 111, D07207, doi:10.1029/2005JD006328, 2006.

Sheridan, P. J. and Ogren, J. A.: Observations of the vertical and regional variability of aerosol optical properties over central and eastern North America, J. Geophys. Res., 104, 16793-16805, 1999.

Shindell, D. T., Chin, M., Dentener, F., Doherty, R. M., Faluvegi, G., Fiore, A. M., Hess, P., Koch, D. M., MacKenzie, I. A., Sanderson, M. G., Schultz, M. G., Schulz, M., Stevenson, D. S., Teich, H., Textor, C., Wild, O., Bergmann, D. J., Bey, I., Bian, H., Cuvelier, C., Duncan, B. N., Folberth, G., Horowitz, L. W., Jonson, J., Kaminski, J. W., Marmer, E., Park, R., Pringle, K. J., Schroeder, S., Szopa, S., Takemura, T., Zeng, G., Keating, T. J., and Zuber, A.: A multi-model assessment of pollution transport to the Arctic, Atmos. Chem. Phys., 8, 5353-5372, doi:10.5194/acp-85353-2008, 2008.

Simpson, I. J., Akagi, S. K., Barletta, B., Blake, N. J., Choi, Y., Diskin, G. S., Fried, A., Fuelberg, H. E., Meinardi, S., Rowland, F. S., Vay, S. A., Weinheimer, A. J., Wennberg, P. O., Wiebring, P., Wisthaler, A., Yang, M., Yokelson, R. J., and Blake, D. R.: Boreal forest fire emissions in fresh Canadian smoke plumes: C1-C10 volatile organic compounds (VOCs), $\mathrm{CO}_{2}, \mathrm{CO}, \mathrm{NO}_{2}$, $\mathrm{NO}, \mathrm{HCN}$ and $\mathrm{CH}_{3} \mathrm{CN}$, Atmos. Chem. Phys., 11, 6445-6463, doi:10.5194/acp-11-6445-2011, 2011.

Sofiev, M., Vankevich, R., Lotjonen M., Prank, M., Petukhov, V., Ermakova, T., Koskinen, J., and Kukkonen, J.: An operational system for the assimilation of satellite information on wild-land fires for the needs of air quality modelling and forecasting, Atmos. Chem. Phys., 9, 6833-6847, doi:10.5194/acp-9-6833-2009, 2009.

Stocks, B. J., Alexander, M. E., and Lanoville, R. A.: Overview of the International Crown Fire Modelling Experiment (ICFME), Canad. J. For. Res., 34, 1543-1547, 2004.

Stohl, A.: Characteristics of atmospheric transport into the Arctic troposphere, J. Geophys. Res., 111, D11306, doi:10.1029/2005JD006888, 2006.

Taipale, R., Ruuskanen, T. M., Rinne, J., Kajos, M. K., Hakola, H., Pohja, T., and Kulmala, M.: Technical Note: Quantitative long-term measurements of VOC concentrations by PTR-MS measurement, calibration, and volume mixing ratio calculation methods, Atmos. Chem. Phys., 8, 6681-6698, doi:10.5194/acp8-6681-2008, 2008.

Taipale, R., Ruuskanen, T. M., Kajos, M. K., Patokoski, J., Hakola, H., and Rinne, J.: VOC emissions from a boreal forest - direct ecosystem scale measurements by PTR-MS in 2006-2008. In:
Contributions - 4th International Conference on Proton Transfer Reaction Mass Spectrometry and its Applications, 299-302, 2009.

Vajda, A., Venäläinen, A., Suomi, I., Junila, P., and Mäkelä, H. M.: Assessment of forest fire danger in a boreal forest environment: description and evaluation of the operational system applied in Finland, Meteorol. Appl., doi:10.1002/met.1425, 2013.

van der Werf, G. R., Randerson, J. T., Giglio, L., Collatz, G. J., Mu, M., Kasibhatla, P. S., Morton, D. C., DeFries, R. S., Jin, Y., and van Leeuwen, T. T.: Global fire emissions and the contribution of deforestation, savanna, forest, agricultural, and peat fires (19972009), Atmos. Chem. Phys., 10, 11707-11735, doi:10.5194/acp10-11707-2010, 2010.

van Leeuwen, T. T. and van der Werf, G. R.: Spatial and temporal variability in the ratio of trace gases emitted from biomass burning, Atmos. Chem. Phys., 11, 3611-3629, doi:10.5194/acp11-3611-2011, 2011.

Virkkula, A., Backman, J., Aalto, P. P., Hulkkonen, M., Riuttanen, L., Nieminen, T., Dal Maso, M., Sogacheva, L., De Leeuw, G., and Kulmala, M.: Seasonal cycle, size dependencies, and source analyses of aerosol optical properties at the SMEAR II measurement station in Hyytiälä, Finland, Atmos. Chem. Phys., 11, 4445-4468, doi:10.5194/acp-11-4445-2011, 2011.

Virkkula, A., Pohja, T, Aalto P., Keronen, P., Schobesberger, S., Clements, C.B., Petäjä, T., and Kulmala, M.: Airborne measurements of aerosols and carbon dioxide during a prescribed fire experiment at a boreal forest site, submitted to Boreal Environ. Res., 2013.

Viro, P. J.: Prescribed Burning in Forestry, Communicationes Instituti Forestalis Fenniae, 67, 1969.

Wade, D. D. and Lunsford, J. D.: A guide to prescribed fire in Southern forests. Tech. Pub. R8-TP 11, Atlanta, GA, USDA Forest Service, Southern Region, 1989.

Ward, D. E. and Hao, W. M.: Air toxic emissions from burning of biomass globally-Preliminary estimates, paper presented at 85th Annual Meeting, Air and Waste Management Association, Vancouver, British Columbia, 1992.

Yli-Ojanperä, J., Kannosto, J., Marjamäki, M., and Keskinen, J.: Improving the nanoparticle resolution of the ELPI. Aerosol Air Qual. Res., 10, 360-366, 2010.

Yokelson, R. J., Griffith, D. W. T., and Ward, D. W.: Openpath Fourier transform infrared studies of large-scale laboratory biomass fires, J. Geophys. Res., 101, 21067-21080, 1996.

Yokelson, R. J., Goode, J. G., Ward, D. E., Susott, R. A., Babbitt, R. E., Wade, D. D., Bertschi, I, Griffith, D. W. T., and Hao, W. M.: Emissions of formaldehyde, acetic acid, methanol, and other trace gases from biomass fires in North Carolina measured by airborne Fourier transform infrared spectroscopy, J. Geophys. Res., 104, 30109-30125, 1999.

Yokelson, R. J., Burling, I. R., Gilman, J. B., Warneke, C., Stockwell, C. E., de Gouw, J., Akagi, S. K., Urbanski, S. P., Veres, P., Roberts, J. M., Kuster, W. C., Reardon, J., Griffith, D. W. T., Johnson, T. J., Hosseini, S., Miller, J. W., Cocker III, D. R., Jung, H., and Weise, D. R.: Coupling field and laboratory measurements to estimate the emission factors of identified and unidentified trace gases for prescribed fires, Atmos. Chem. Phys., 13, 89-116, doi:10.5194/acp-13-89-2013, 2013. 


\section{Appendix A}

Table A1. Acronyms and abbreviations.

\begin{tabular}{|c|c|}
\hline$\delta$ & Aerosol optical depth \\
\hline$\sigma_{\mathrm{sp}}$ & Scattering coefficient \\
\hline$\sigma_{\mathrm{bsp}}$ & Backscattering coefficient \\
\hline$\sigma_{\mathrm{ap}}$ & Absorption coefficient \\
\hline$\omega_{0}$ & Single-scattering albedo \\
\hline$\alpha_{\mathrm{sp}}$ & Ångström exponent of scattering \\
\hline$\Delta F / \delta$ & Radiative forcing efficiency \\
\hline AMS & Aerosol Mass Spectrometer \\
\hline a.m.s.l. & Above mean sea level \\
\hline APS & Aerodynamic particle sizer \\
\hline$b$ & Backscatter fraction \\
\hline $\mathrm{CPC}$ & Condensation particle counters \\
\hline DBH & Diameter at breast height \\
\hline DMPS & Differential mobility particle sizer \\
\hline EET & Eastern European Time $=\mathrm{UTC}+2 \mathrm{~h}$ \\
\hline $\mathrm{EF}$ & Emission factor \\
\hline ELPI & Electrical Low Pressure Impactor \\
\hline$E R$ & Emission ratio \\
\hline FFI & Forest Fire Index \\
\hline$H_{\mathrm{S}}$ & Sensible heat flux \\
\hline MAAP & Multi-Angle Absorption Photometer \\
\hline MCE & Modified combustion efficiency \\
\hline MISR & Multi-angle Imaging SpectroRadiometer \\
\hline MODIS & $\begin{array}{l}\text { Moderate Resolution Imaging Spectroradiome- } \\
\text { ter }\end{array}$ \\
\hline$m / z$ & Mass-to-charge ratio \\
\hline PTR-MS & Proton Transfer Reaction Mass Spectrometer \\
\hline$Q$ & Total heat flux \\
\hline REA & Relaxed eddy accumulation \\
\hline ROS & Rate of fire spread \\
\hline SMEAR & $\begin{array}{l}\text { Station for Measuring Ecosystem-Atmosphere } \\
\text { Relations }\end{array}$ \\
\hline TDMPS & Twin differential mobility particle sizer \\
\hline TKE & Turbulent kinetic energy \\
\hline VOC & Volatile organic compound \\
\hline$w$ & Vertical velocity \\
\hline WD & Wind direction \\
\hline WS & Horizontal wind speed \\
\hline
\end{tabular}

